USGS Open-File Report $95-820$

\author{
U. S. DEPARTMENT OF THE INTERIOR \\ U. S. GEOLOGICAL SURVEY
}

\title{
BREAKS IN PAVEMENT AND PIPES AS INDICATORS OF RANGE-FRONT FAULTING RESULTING FROM THE 1989 \\ LOMA PRIETA EARTHQUAKE NEAR THE SOUTHWEST MARGIN OF THE SANTA CLARA VALLEY, CALIFORNIA
}

\author{
by \\ Kevin M. Schmidt', Stephen D. Ellen ${ }^{2}$, Ralph A. Haugerud ${ }^{3}$, \\ David M. Peterson ${ }^{4}$, and Geoffrey A. Phelps ${ }^{2}$
}

1995

\section{Open-File Report $\mathbf{9 5 - 8 2 0}$}

This report is preliminary and has not been reviewed for conformity with U.S. Geological Survey editorial standards (or with the North American Stratigraphic Code). Any use of trade, product, or firm names is for descriptive purposes only and does not imply endorsement by the U.S. Government.

$\begin{array}{lclc}\text { 'Present Address: } & { }^{2} \text { Menlo Park, CA } & { }^{3} \text { U.S.G.S. } & 4 \text { P.O. Box } 1460 \\ \text { University of Washington } & 94025 & \text { University of Washington } & \text { Los Alamos, NM } \\ \text { Dept. of Geological Sciences } & & \text { Seattle, WA } 98195 & 87544 \\ \text { Box 351310 } & & & \\ \text { Seattle, WA } 98195 & & & \end{array}$




\section{CONTENTS}

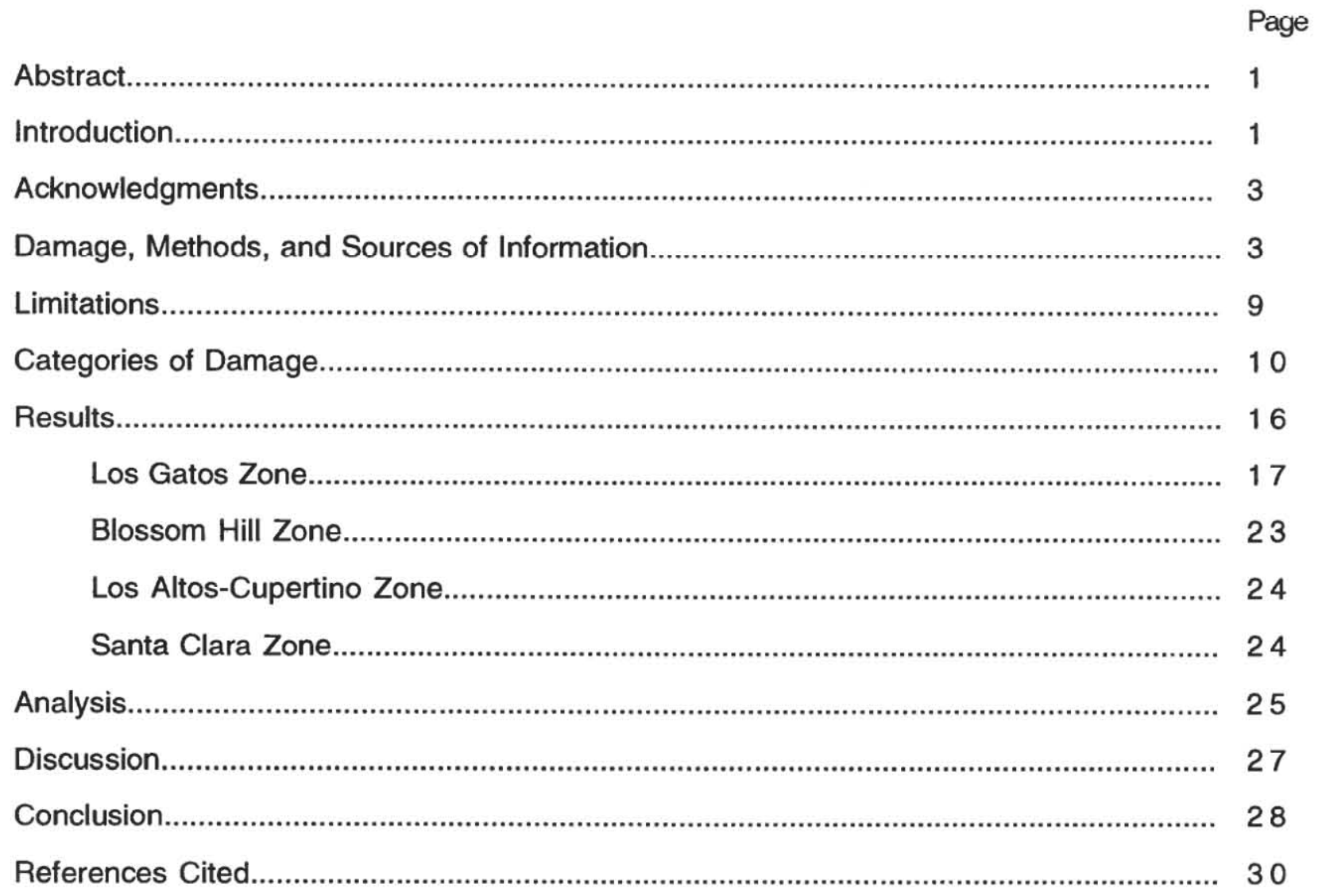

\section{ILLUSTRATIONS}

\section{FIGURE}

1. Index map showing location of study area, faults, and damage zones....................... 2

2. Photograph showing break in concrete curb....................................................... 4

3. Photograph showing thrust in NNE-trending sidewalk......................................... 4

4. Photograph showing buckled concrete slabs along northwest-trending street......... 5

5. Photograph showing storm-drain grate shortened by coseismic

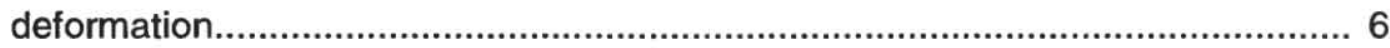

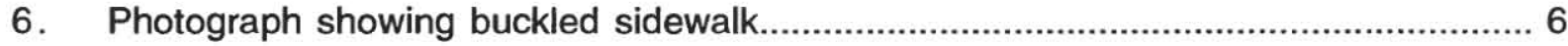

7. Photograph showing complex cracks in asphalt parking lot............................... 11 
8. Photograph showing deformed concrete curb and gutter....................................... 13

9. Schematic map and profile showing measured deformation in sidewalk................... 14

10. Photograph showing post-earthquake thrust in asphalt sidewalk patch................... 18

11. Photographs showing post-earthquake sidewalk deformation.................................. 19

12. Photographs showing coseismic breaks along exposed fault contact........................ $21 \& 22$

TABLE

1. Sources of information on damage to pavement and pipes, listed by category of damage 8

\section{PLATE}

1. Map showing distribution of breaks in pavement and pipes near the southwest margin of the Santa Clara Valley, California.

2. Map showing subset of damage to pavement and pipes near Los Gatos, Cupertino, and Los Altos Hills. 


\title{
BREAKS IN PAVEMENT AND PIPES AS INDICATORS OF RANGE-FRONT FAULTING RESULTING FROM THE 1989 LOMA PRIETA EARTHQUAKE NEAR THE SOUTHWEST MARGIN OF THE SANTA CLARA VALLEY, CALIFORNIA
}

\author{
Kevin M. Schmidt, Stephen D. Ellen, Ralph A. Haugerud, \\ David M. Peterson, and Geoffrey A. Phelps
}

\begin{abstract}
Damage to pavement and near-surface utility pipes, caused by the October 17, 1989, Loma Prieta earthquake, provide indicators for ground deformation in a $663 \mathrm{~km}^{2}$ area near the southwest margin of the Santa Clara Valley, California. The spatial distribution of 1284 sites of such damage documents the extent and distribution of detectable ground deformation. Damage was concentrated in four zones, three of which are near previously mapped faults. The zone through Los Gatos showed the highest concentration of damage, as well as evidence for pre- and post-earthquake deformation. Damage along the foot of the Santa Cruz Mountains reflected shortening that is consistent with movement along reverse faults in the region and with the hypothesis that tectonic strain is distributed widely across numerous faults in the California Coast Ranges.
\end{abstract}

\section{INTRODUCTION}

Damage from the Loma Prieta earthquake included numerous breaks in pavement and pipes near the southwest margin of the Santa Clara Valley, a heavily populated area between the Santa Cruz Mountains and the San Francisco Bay (fig. 1). Except for slope failures along reservoir margins, displacements were rarely detected in soil or bedrock, but brittle manmade structures in contact with the ground, such as pavement and underground utility lines, displayed widespread damage. We used damage to these and similar man-made structures to document the spatial extent and character of earthquake-induced ground deformation in this area.

Pavement damage consisted primarily of buckled or thrust concrete curbs (fig. 2) and sidewalk slabs (figs. 3,4 ) indicative of shortening; adjacent asphalt street surfaces typically 

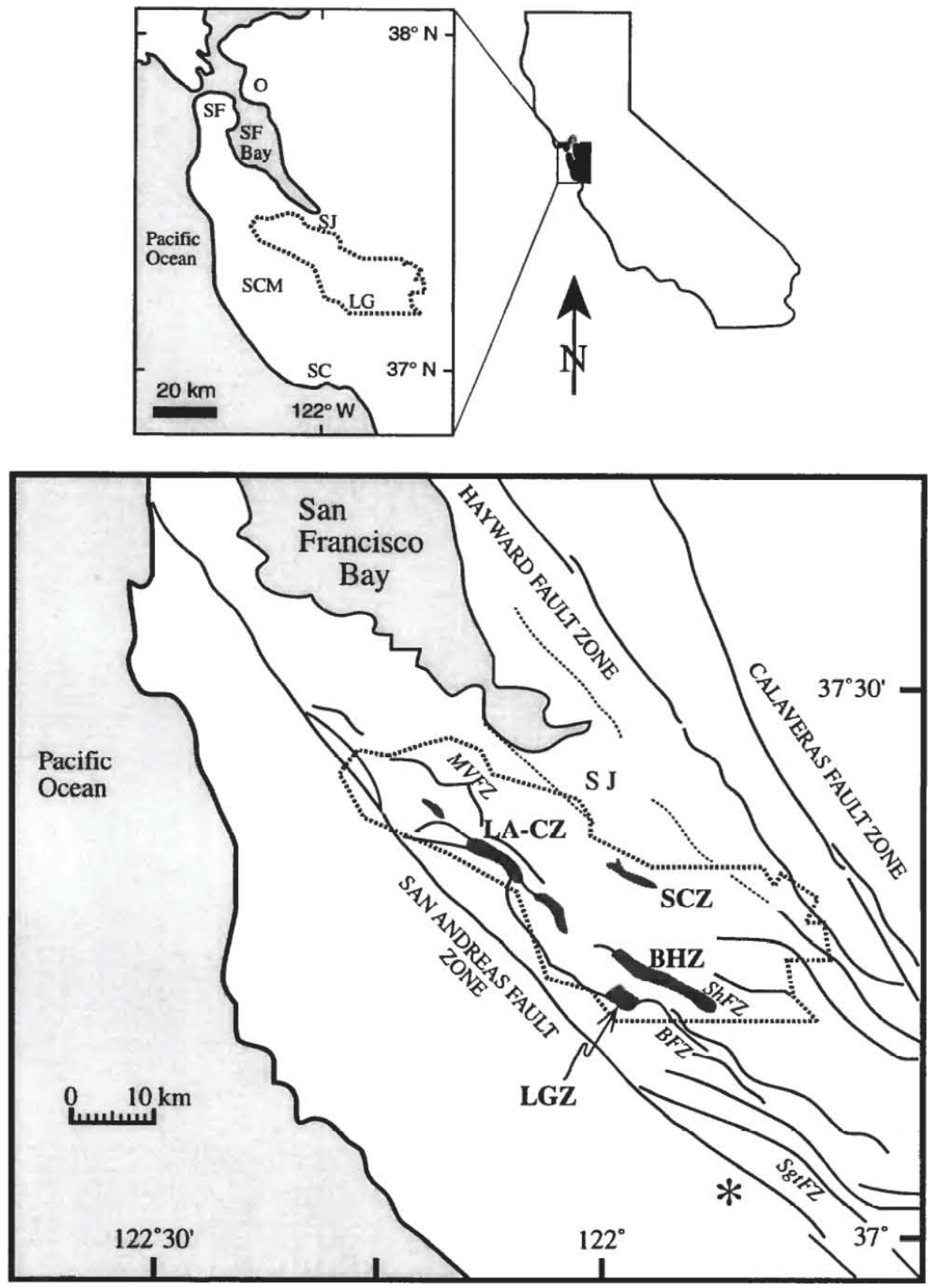

Figure 1. Index maps of the San Francisco Bay region, showing location of the study area (plate a), depicted by dashed polygon, in relation to the cities of Santa Cruz (SC), Los Gatos (LG), San Jose (SJ), San Francisco (SF), and Oakland (O). Study area lies largely in the alluvial lowland of the Santa Clara Valley between steep uplands of the Santa Cruz Mountains (SCM) and estuarine muds of the San Francisco Bay (SF Bay). Lower: Fault map of the southern San Francisco Bay Area with zones of coseismic Loma Prieta earthquake damage. Fault abbreviations: $M V F Z$, Monte Vista fault zone; ShFZ, Shannon fault zone; BFZ, Berrocal fault zone; and SgtFZ, Sargent fault zone. Dashed faults are uncertain. Damage zones: LGZ, Los Gatos zone; BHZ, Blossom Hill zone; SCZ, Santa Clara zone; and LA-CZ, Los Altos-Cupertino zone are depicted by shading. * denotes the epicentral location of the Loma Prieta earthquake. Modified from Aydin and Page (1984). 
lacked damage. Such damage principally affected pavement along NS- and NNE-trending streets. Eyewitness accounts during the earthquake describe spectacular deformation consistent with shortening, including the violent ejection of a manhole cover and a curb popping up into the air then through the rear window of a car. After the earthquake, evidence of shortening included utility-box lids that no longer fit into their casings and distorted storm-drain gratings (fig. 5).

In an attempt to document the damage and gain some understanding of its origin, we mapped and compiled the distribution of 1284 sites of coseismic damage to pavement and pipes over a $663 \mathrm{~km}^{2}$ area in the southwest part of the Santa Clara Valley, as shown in plates 1 and 2. In this paper, we describe the damage documented on these plates and our methods of compiling it, then discuss its distribution, relation to geologic features, and likely origin. In the two accompanying papers (Peterson and others, in press; Ellen and others, in press), we describe some of this damage in more detail and report on measurements of permanent ground deformation associated with the damage.

\section{ACKNOWLEDGMENTS}

The public and private agencies listed in table 1 provided information for this compilation. We greatly appreciate their helpful cooperation. Field observations by the authors were supplemented by information from other U.S. Geological Survey (USGS) personnel, including Edwin L. Harp, Randall W. Jibson, Robert J. McLaughlin, Dennis H. Sorg, and John C. Tinsley, as well as USGS volunteers Julian Bommer (Imperial College, London, England), Mauro Cardinale (CNR, IRPI, Perugia, Italy), K. H. Chang, and Sam Donaldson. Donna L. Knifong provided initial digital preparation of the maps and assisted in the field. Comments from Tinsley, Carl M. Wentworth, David R. Montgomery, and Jonathon Stock improved the text.

\section{DAMAGE, METHODS, AND SOURCES OF INFORMATION}

Detectable ground rupture in natural earth materials was rare in the study area, and so damage to man-made structures and utilities, in particular pavement and pressurized pipelines, provided the major mappable indicator of coseismic ground deformation. Individual breaks typically were not prominent enough to provide measurable displacements, and local alignments of breaks were detectable in only a few places, as described below in the section entitled "Results." Consequently, the spatial distribution of this damage provided the principal evidence of its origin. We assembled information on such damage by mapping it's occurrence in the field and by compiling reports of damage from utility companies and public agencies. 


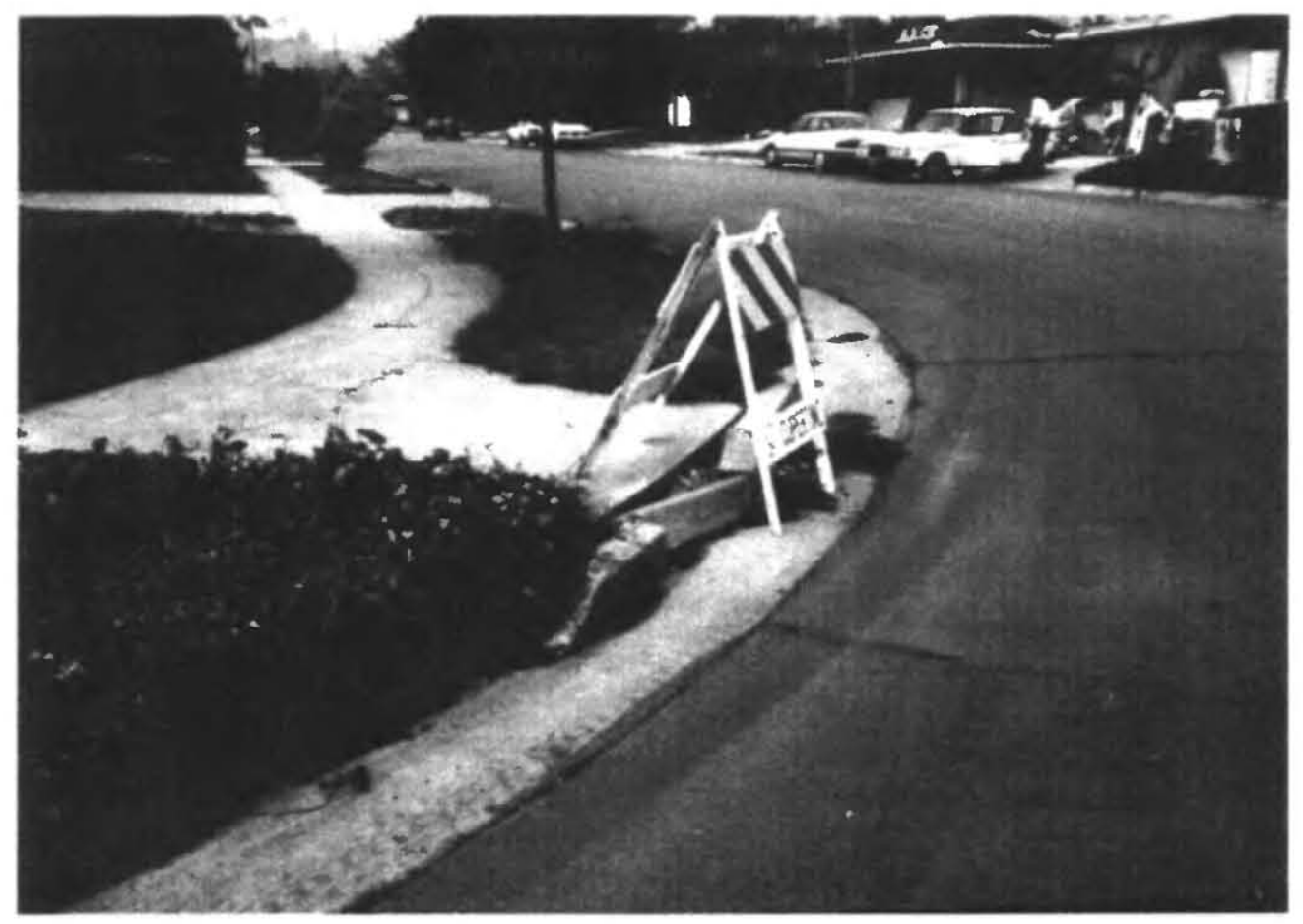

Figure 2. Contractional deformation of concrete curb at street corner in Cupertino, in Los Altos-Cupertino zone. Photograph taken February 1990 by S.D. Ellen.

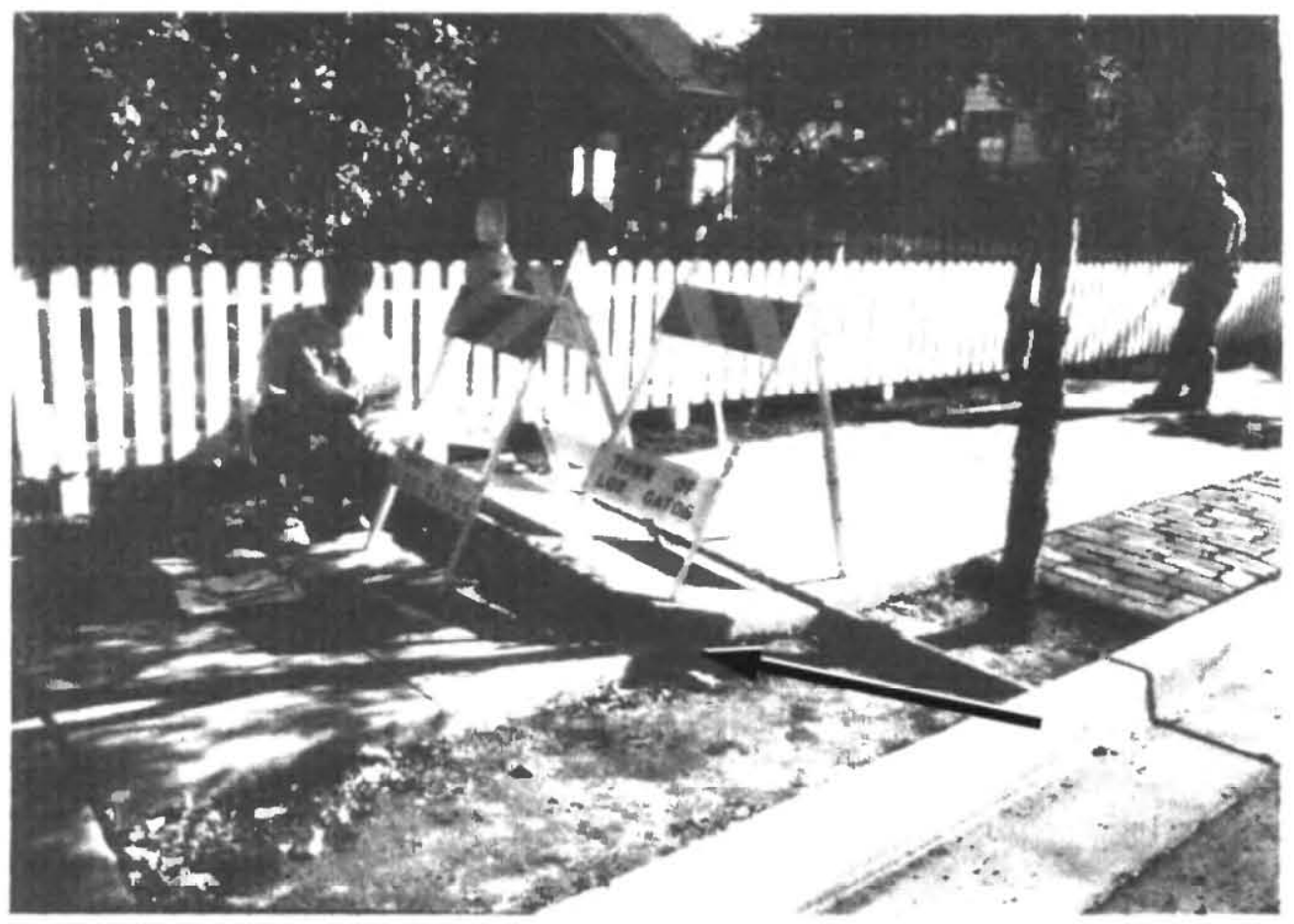

Figure 3. Thrust in NNE-trending sidewalk in Los Gatos, on University Avenue near Royce Street, looking southeast. Thrust, denoted by arrow, showed $12 \mathrm{~cm}$ of shortening. Adjacent curb showed no deformation. Photograph taken November 1989 by S.D. Ellen. 


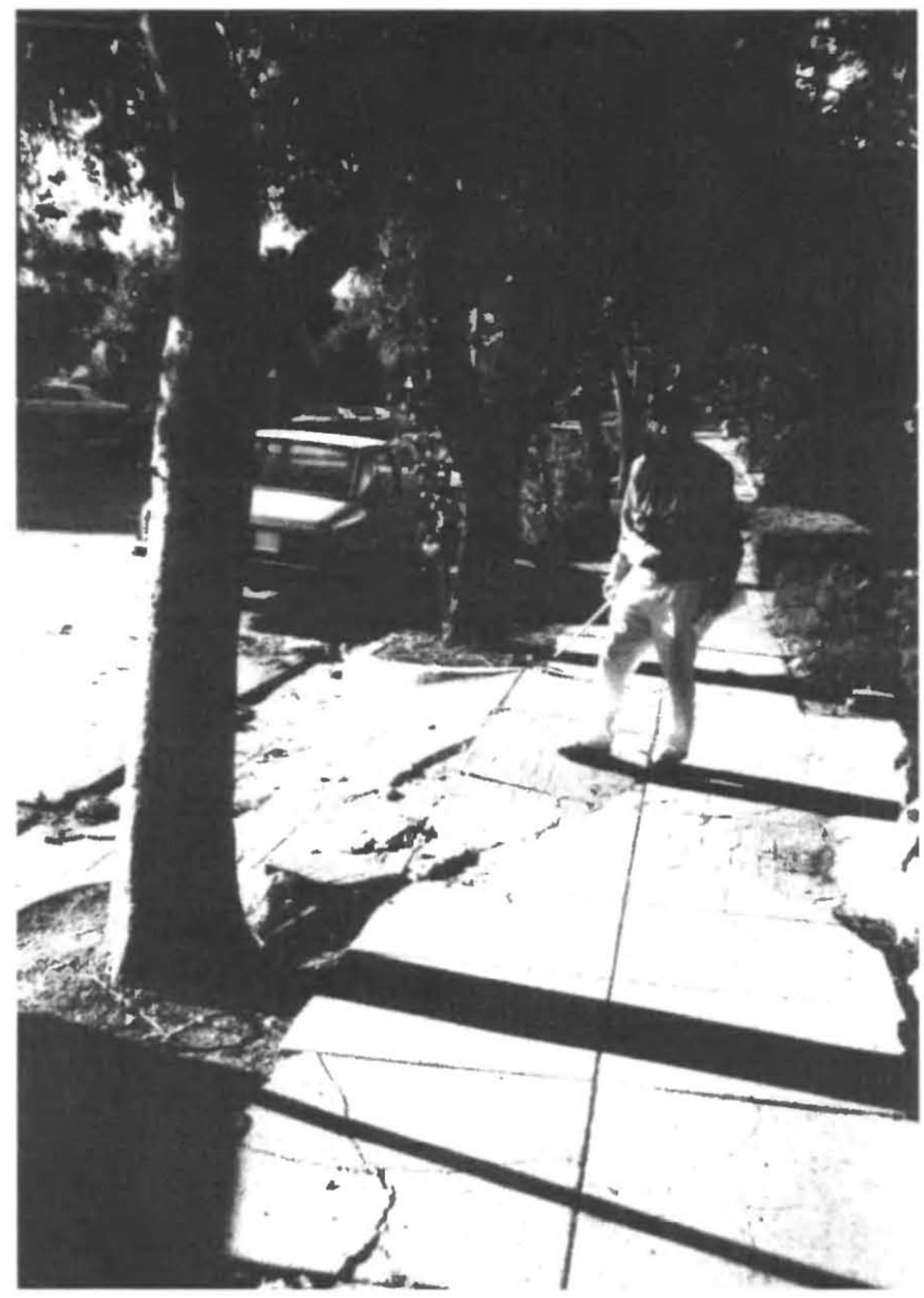

Figure 4. Buckled concrete slabs of sidewalk and driveway along WNW-trending street in Los Gatos, looking northwest. Contractional deformation along streets of this orientation was uncommon. The deformation in this photograph suggests shortening perpendicular to the street, apparently resulting from shortening along the driveway that extends across sidewalk. Photograph taken October or November 1989 by S.D. Ellen. 


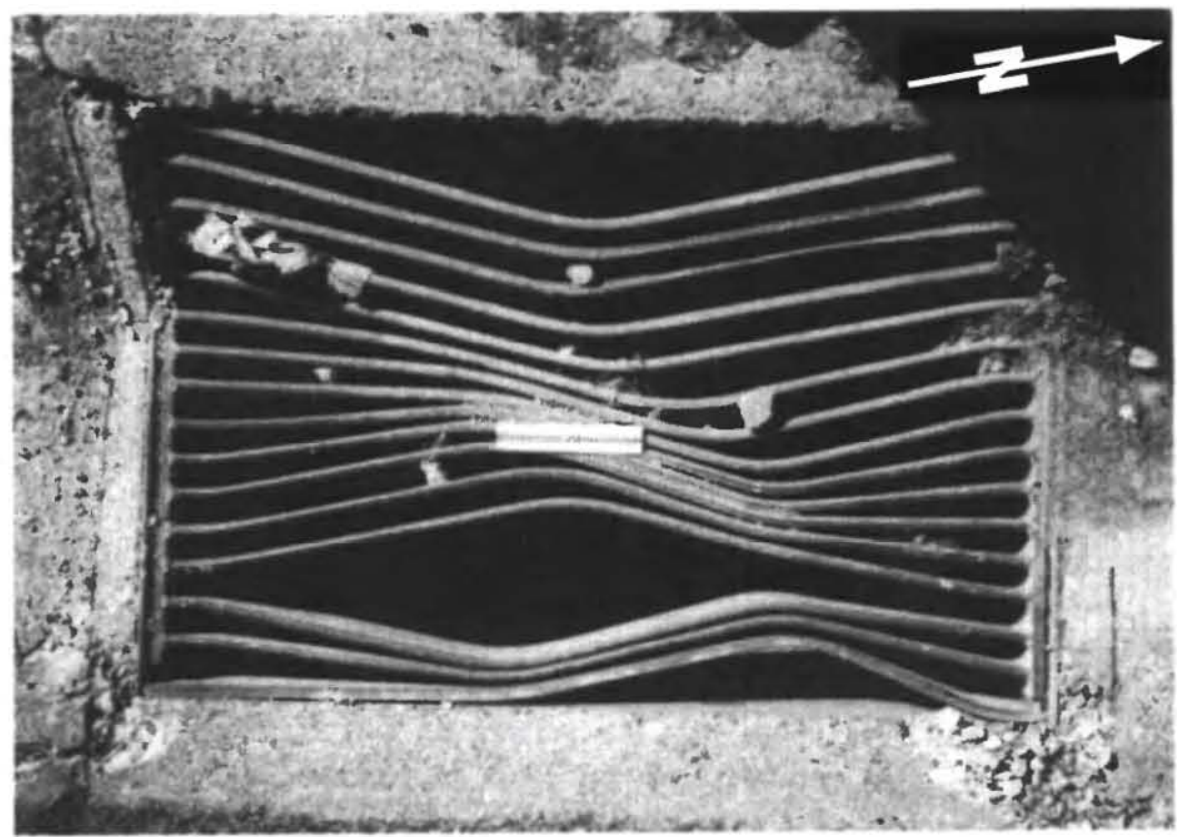

Figure 5. Storm-drain grate shortened by coseismic deformation, in onramp to southbound State Highway 17 at State Route 9 in Los Gatos. Scale in center is about $18 \mathrm{~cm}$ long. Note spalled concrete at corners of grate. Photograph taken late October 1989 by R.A. Haugerud.

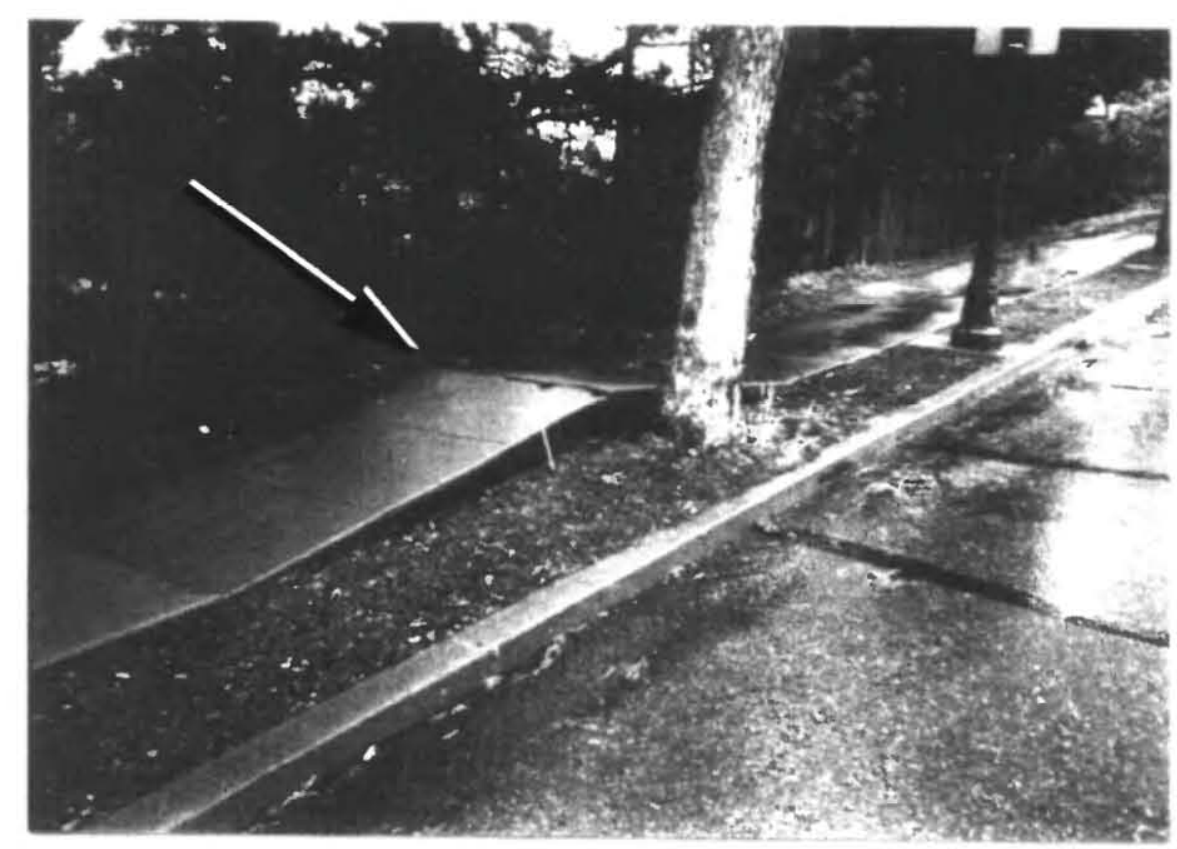

Figure 6. Buckled sidewalk, denoted by arrow, showing common occurrence at places where pre-earthquake displacement by tree roots provided initial deflection. Photograph taken late October 1989 by S.D. Ellen. 
We did not compile all types of earthquake damage in the area, but we were thorough in including information from all likely sources on damage to pavement and pressurized pipelines. The types of damage compiled here are limited primarily to those situated at or below the ground surface (depth $<1.4 \mathrm{~m}$ ). The exception is above-ground breaks of natural-gas lines, which account for about five percent of the data set. Subsurface storm drains and sewer pipes were excluded from the search because leaks are not easily detected. Although damage to buildings was common, it was not documented in this study because it is especially sensitive to building design, construction methods, and quality of materials.

The majority of the evidence (almost two-thirds of the data) consisted of freshly broken, buckled, or spalled concrete sidewalks, curbs, gutters, and streets. This type of damage reflected shortening along the length of the concrete. Owing to its rigidity, concrete, where it occurs in long strips such as streets, curbs, and sidewalks, can transmit small amounts of contractive strain across broad zones. Thus, during the earthquake, contractive strain could accumulate over substantial lengths of concrete, to be revealed at a single prominent buckle or break. Similar magnitudes of extensional strains generally were not revealed because concrete pavement typically includes expansion joints or pre-existing cracks, which can accommodate small amounts of extension without detectable damage. Likewise, shear across concrete strips was not clearly displayed, perhaps because small lateral strains could be accommodated along pre-existing cracks and expansion joints. Thus, only contractive strains were effectively revealed by the damage to concrete.

Damage to pavement and water lines was located in the field by driving slowly along streets, then examined on foot. Areas of abundant damage were examined and mapped on foot from public right-of-ways. We made a concerted effort to search systematically, without regard to preconceived trends or recognized zones of damage, so as to obtain an objective and complete portrayal of distribution. This field mapping of damage was conducted largely from October 21, 1989, within several days of the earthquake, to December of that year. Monitoring of sites displaying post-earthquake deformation, field checking of address locations from damage listings, and measurement of displacements continued into the autumn of 1990.

To augment field observations, we contacted all recognized governmental and publicservice agencies responsible for repairing or cataloging damage within the study area. The more than 30 agencies listed in table 1 contributed maps or address listings of damage. Except for those points identified on plates 1 and 2 as pre- or post-earthquake deformation, all damage compiled from these agencies had been reported to them on the date of the earthquake or shortly thereafter, and so is assumed to have occurred during the main shock. To avoid introducing any bias to the distribution of damage, we did not edit the reports of damage. For example, the uncommonly abundant sidewalk repairs reported along Belgatos Road north of Blossom Hill, 
Table 1: Sources of information on damage to pavement and pipes, listed by category of damage.

NATURAL GAS LINES

1. City of Palo Alto

2. Pacific Gas and Electric Company (Belmont, Cinnabar, and

De Anza Districts)

3. Stanford University

WATER LINES

1. California Water Service Company

2. City of Cupertino

3. City of Menlo Park

4. City of Mountain View

5. City of Palo Alto

6. Town of Portola Valley

7. City of San Jose

8. City of Saratoga

9. City of Santa Clara

10. City of Sunnyvale

11. Great Oaks Water Company

12. Purissima Hills County Water District

13. San Jose Water Company

14. Santa Clara Valley Water District

15. Stanford University

16. William Cotton and Associates

PAVEMENT BREAKS

1. City of Cupertino

2. City of Los Altos

3. Town of Los Altos Hills

4. City of Menlo Park

5. City of Monte Sereno

6. City of Mountain View

7. City of Palo Alto

8. Town of Portola Valley

9. City of San Jose

10. City of Santa Clara

11. City of Saratoga

12. City of Sunnyvale

13. Stanford University

14. Town of Los Gatos

15. Leslie Ransbottom and Walter Dibble of JCP Engineers and Geologists, Inc.

16. William Cotton and Associates

17. William F. Cole of William Cotton and Associates 
which may result principally from long-term tree-root damage, are shown in plates 1 and 2 despite few USGS observations of fresh breaks.

Sites of damage were plotted on stable-base copies of USGS 7.5-minute topographic quadrangles. The sites were then digitized and plotted on digital mosaics of USGS topographic quadrangles. Plates 1 and 2 combine the damage and base maps with previously mapped faults (from Brabb and others, in prep.; Wentworth and others, in prep.) and with shading that represents hillside areas underlain by bedrock (from Wentworth, 1993).

The boundary of the study area (fig. 1) was chosen to include the bulk of the kind of damage described above and to exclude, as much as possible, ambiguous evidence. The boundary was chosen to exclude liquefaction-induced damage near San Francisco Bay. Similarly, to exclude any damage resulting from gravitational movement, our mapping and compilation focused mainly on the alluvial lowlands, and so our field observations may be incomplete in the hills.

\section{LIMITATIONS}

The principal uncertainties in field observations were distinguishing coseismic damage from other damage and determining the sense of deformation. Damage to concrete was considered coseismic where cracks and spalls showed light-colored, unweathered surfaces. We inferred shortening where pavement was damaged in a manner consistent with shortening, typically by thrusting or buckling (figs. 3-6, 10). The coseismic origin of cracks in asphalt was determined by close examination, combined with proximity to coseismic damage in concrete and pipes. Leaks in water pipes were assumed to have been caused by the earthquake if they were reported or observed in the period immediately following the earthquake.

The information on coseismic damage reported here has a number of additional uncertainties. For instance, the pavement and pipes that provided the primary strain markers are also subject to non-seismic damage. Buckling of concrete sidewalks, for example, was probably of mixed origin where upheaval by tree roots appeared to have previously cracked and deflected the concrete (fig. 6). In addition, earthquake-generated strains may have been irregularly reflected in the damage because the strength of the strain markers, and hence their sensitivity to ground deformation, is influenced by variation in quality of the original construction, history of maintenance, and age. Damage in some upland areas may reflect unrecognized slope failures rather than tectonic strains. Times of damage-generation are not known in detail, and so some of the damage may actually have occurred in response to foreshocks or aftershocks. 
The principal limitation, though, is the spatial distribution of concrete and pipes. Concrete pavement, in the form of curbs, gutters, sidewalks, and streets, is largely limited to the regular network of straight streets in the flatland areas, and even here is not everywhere present. In many parts of the map, lack of damage may simply reflect a lack of concrete and pipes rather than absence of ground deformation.

\section{CATEGORIES OF DAMAGE}

This section describes the categories used in plates 1 and 2 to portray the distribution of damage. The categories are described in the order of the map explanation, which in a general way is arranged by decreasing severity of damage.

\section{COSEISMIC PAVEMENT BREAKS}

IN ASPHALT

\section{Linear zone of complex rupture}

These three locations of major breakage in asphalt parking areas and playgrounds are noteworthy because of the scarcity of significant damage to asphalt. The breaks were each $30 \mathrm{~m}$ or more in length (fig. 7). They displayed complex cracking, the intricate details of which appeared to be controlled largely by man-made structural features of the pavement. Each of these breaks occurred near the center of a damage zone defined largely by breaks in concrete, and each trended northwest, about parallel to the trend of surrounding damage. These breaks seem to mark the hearts of the damage zones, and their occurrence there makes sense because breakage of ductile asphalt appears to have required greater or more rapid deformation than breakage of more brittle concrete or buried pipes.

\section{Fresh break or buckle suggestive of contractional deformation}

These 11 sites were mainly buckles across asphalt highway surfaces. The development of buckles at the two sites near Los Altos Hills was witnessed during the main shock by consulting geologist Leslie Ransbottom (written commun., 1990).

\section{Fresh break with unspecified sense of deformation}

Most of these breaks were minor open cracks in asphalt road surfaces. Such breaks were not mapped systematically over the study area, and so the maps are incomplete in depicting this category of damage. 


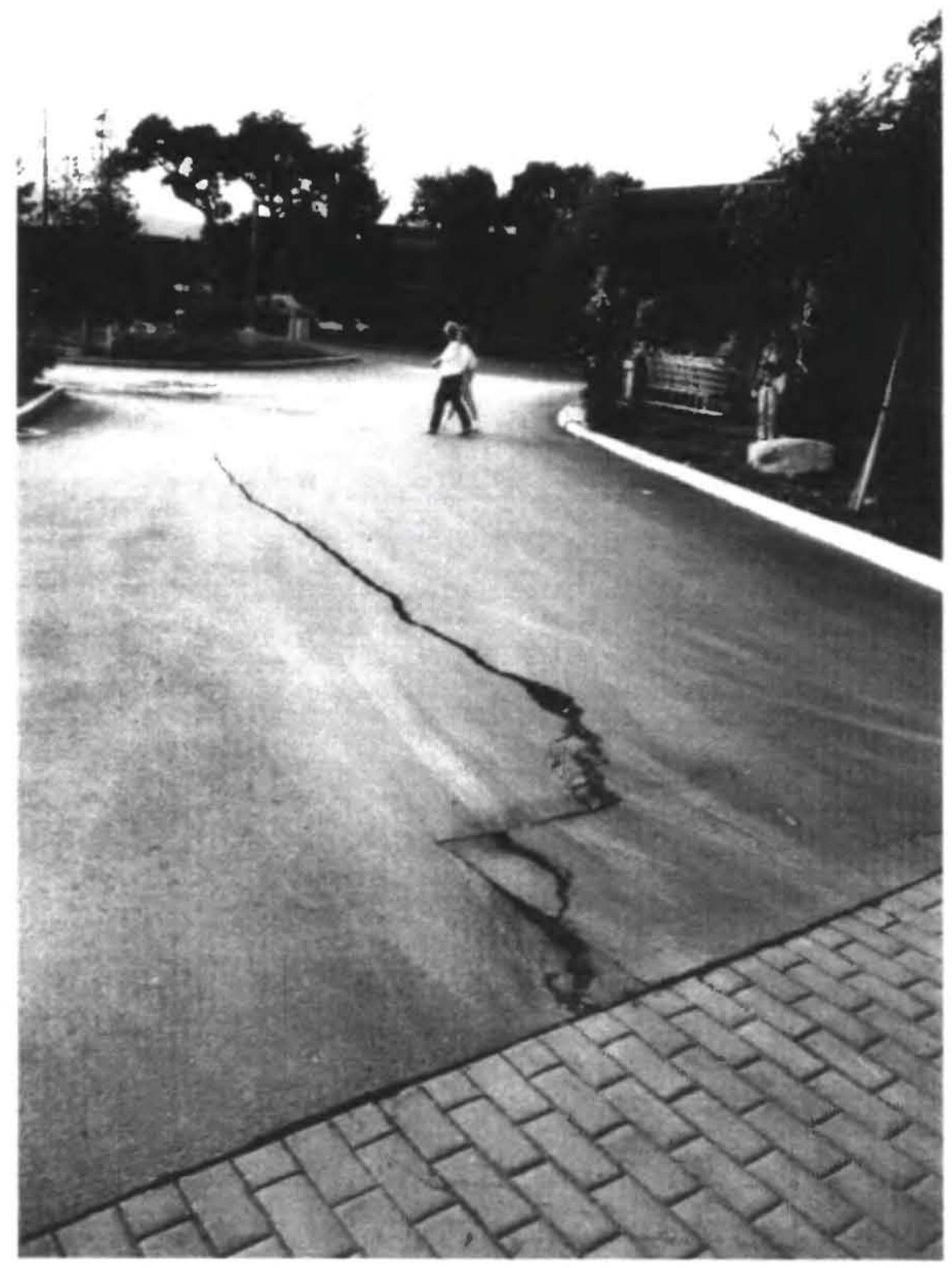

Figure 7. Northwest-trending cracks in asphalt at Village Square shopping center, on Los Gatos Boulevard near Gateway Drive in Los Gatos, looking west. Photograph taken late October 1989 by S.D. Ellen. 


\section{INCONCRETE}

\section{Fresh contractional break in channel lining of Los Gatos Creek}

These sites were largely thrusts of measured displacement and showed a total of $160-170 \mathrm{~mm}$ of net horizontal shortening along the trend of the lined portion of the channel. They are described by Peterson and others (in press).

\section{Fresh break or buckle suggestive of contractional deformation}

These 364 sites consisted largely of thrusts in curbs and gutters, and include the conspicuous buckles and thrusts in sidewalks that have become symbolic of coseismic pavement damage in the area (figs. 2-4, 6, 8). We systematically mapped these features, and the plates are thorough in portraying their distribution. Damage was concentrated within strips of NS- or NNE-trending concrete. Many sites are at street corners, where sidewalks terminate or curve abruptly, leaving free surfaces unsupported by adjacent pavement (fig. 2). Adjacent asphalt typically lacked damage.

This category includes damage with displacements that varied from a few millimeters to $100 \mathrm{~mm}$ or more. Buckling and thrusting of sidewalks was prominent (fig. 3), but typically reflected shortening of only a few centimeters. Three attempts at careful measurement of sidewalk displacements along city blocks with pronounced buckling revealed little or no net shortening, because several inconspicuous extensional cracks accompanied each of the three sites (fig. 9). Because prominence of buckling did not reflect magnitude of net displacement, we ceased attempts to measure displacements associated with this damage and relied instead on geodetic and other measurements (Ellen and others, in press; Peterson and others, in press). Damage of this category was especially suggestive of faulting where concentrations were dense or where concrete was broken in close proximity on both sides of a street, suggesting a narrow, throughgoing zone of deformation.

\section{Apparently fresh break with unspecified sense of deformation}

These 171 sites, mapped largely by the authors, consisted of smaller concrete breaks that were either less convincingly fresh or less clearly contractional.

Break with unspecified sense of deformation

These 273 sites consisted of breaks in sidewalks, curbs, gutters, and concrete streets reported by local governments as caused by the earthquake. The magnitude and significance of these breaks were variable. Although some may represent preexisting damage (most commonly from tree roots) that was accentuated by the earthquake, field observations indicated that most represent significant coseismic damage. 


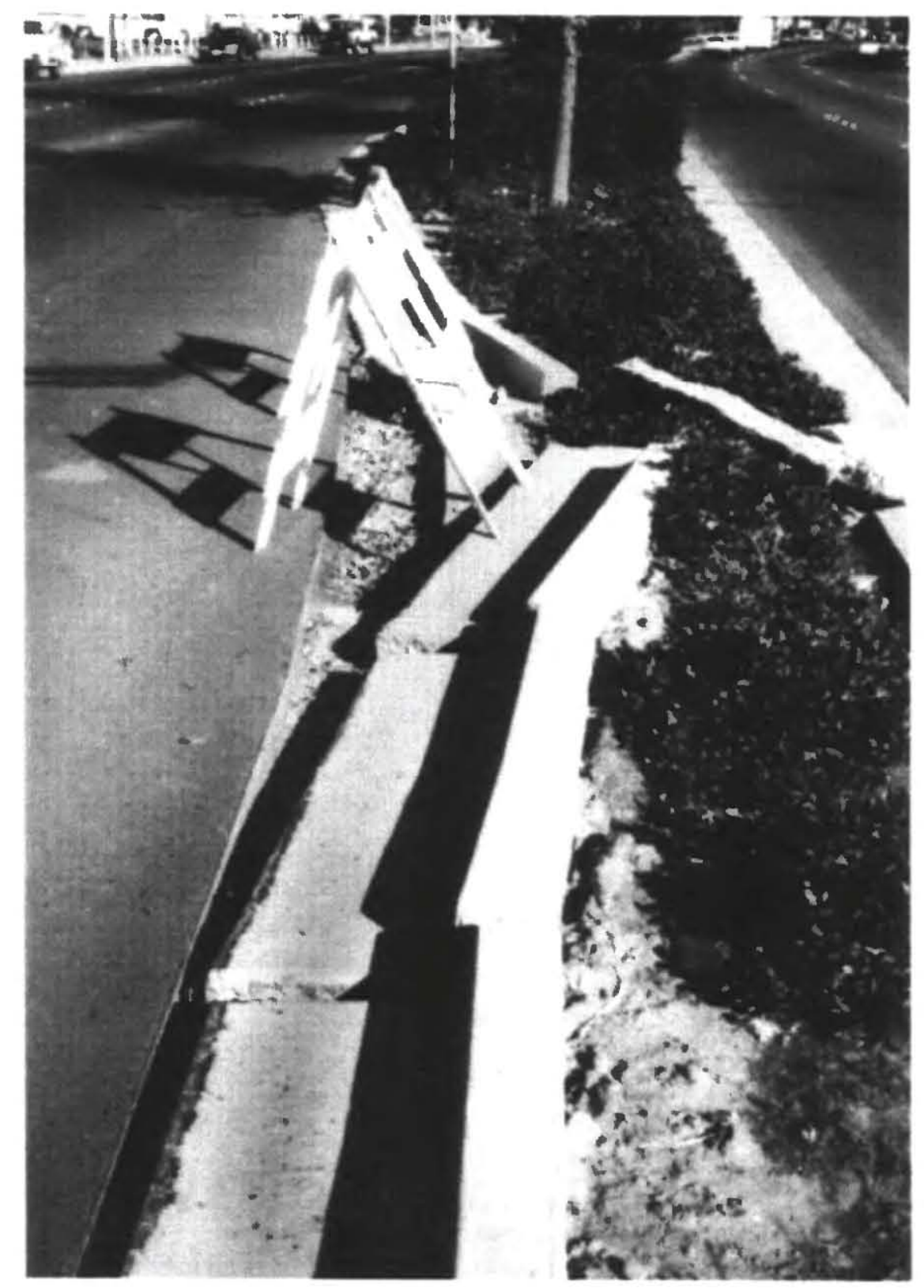

Figure 8. Contractional deformation and lateral deflection of concrete curb and gutter on Los Gatos Boulevard near the Village Square shopping center, looking northeast toward intersection with Gateway Drive. Photograph taken December 5, 1989, by J.C Tinsley, U.S. Geological Survey. 


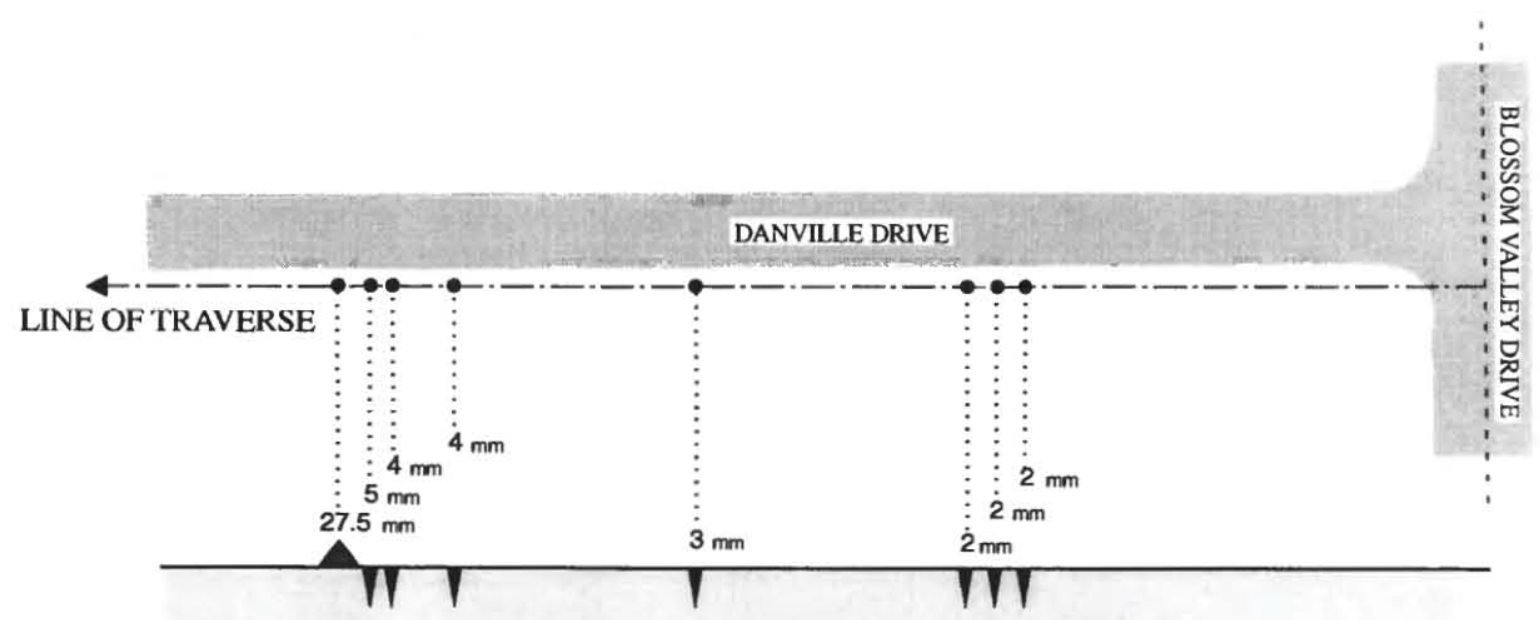

Net Shortening: $5.5 \mathrm{~mm}$

$\Delta=$ shortening in tent-structure or thrust
$\boldsymbol{\nabla}=$ extension crack

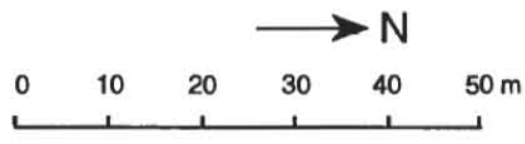

Figure 9. Schematic map and profile of measured deformation in concrete sidewalk along east side of Danville Drive in Los Gatos, showing tent structure and associated extension cracks. Extension cracks reduce the net shortening from $27.5 \mathrm{~mm}$, measured at the prominent tent structure, to $5.5 \mathrm{~mm}$. Measured at center of sidewalk by $\mathrm{K}$. $\mathrm{H}$. Chang and Mauro Cardinale, November 7, 1989. 


\section{IN BOTH ASPHALT AND CONCRETE}

This category indicates breaks in both asphalt and concrete that were too close together to plot separately, typically at a single address.

EXTENSIONAL RUPTURE IN BOTH PAVEMENT AND NATURAL SOIL

Breaks that involved natural soil were reported in only seven places. All were in sloping ground, and all showed extension, suggesting that they may have resulted from coseismic slope movement.

\section{COSEISMIC PIPE BREAKS}

\section{Underground water line}

Most of these 280 breaks were reported by local governments and utility companies, but some were noted by the authors in the field. No sense of deformation was recorded. The vast majority were reported to the agencies within 24 hours of the earthquake. Underground natural-gas distribution line

These 47 breaks were reported by utility companies and a local government. Breaks to these lines were likewise commonly reported to the agencies within 24 hours of the earthquake.

\section{Above-ground natural-gas distribution line}

These 60 breaks, reported by a utility company, were largely in the vertical "riser" pipes that extend from the ground surface to gas meters, which are located low on the outside walls of buildings. These were the only above-ground breaks compiled for this study; others were excluded because above-ground structures appear to be less reliable indicators of ground displacement than structures at or below the ground surface. We included these particular above-ground breaks because the data were available and systematically compiled, and because of their common occurrence near underground pipe breaks, suggesting that both kinds arose from a common cause. A separate symbol distinguishes these above-ground breaks from other damage.

More than one type of pipe

This category represents pipe breaks that are too close together to plot separately, typically at a single address.

\section{OTHERBREAKS}

\section{In both pipe and pavement}

This category represents breaks in pipe and pavement that were too close together to plot separately, typically at a single address. 


\section{Pavement break that pre-dates the earthquake}

These breaks were all in concrete. One is particularly noteworthy because it was reported to have occurred within the two months prior to the earthquake, suggesting premonitory fault creep; it is described below under "Los Gatos Zone." The other preearthquake breaks appear old, may have arisen from a variety of causes, and were not mapped systematically. Many other old breaks undoubtedly exist.

Combination of pre-earthquake and coseismic break in pavement

Deformation at these six sites suggests recurrent tectonic movement.

\section{Contractional deformation that post-dates the earthquake}

Pavement at four locations in Los Gatos deformed detectably during the days, weeks, and months following the earthquake. At one site we measured more than $10 \mathrm{~mm}$ of shortening over a period of seven months following the earthquake. These sites are described further in the section entitled "Los Gatos Zone."

\section{RESULTS}

The 1284 locations shown in plate 1 delineate a swath of damage that extends northwest parallel to the foot of the Santa Cruz Mountains, as well as a diffuse scatter of damage over the remaining alluvial flatlands. Concrete breaks constitute $64 \%$ of the mapped damage sites, asphalt breaks about $3 \%$, pipe breaks about $31 \%$, and other damage categories constitute the remaining $2-3 \%$ of the sites. Damage at $30 \%$ of the sites suggested shortening. Spatially, the sites are clustered, with $54 \%$ of the total damage contained within the Los Gatos 7.5-minute quadrangle. Because so much of the damage was concentrated in Los Gatos, an enlarged map of this area is shown in plate 2 , so that details, such as the concentration of damage on NNEtrending streets, can be portrayed.

Much of the damage near the mountain front suggested shortening normal to the mountain front. Breaks and buckles in concrete streets, sidewalks, curbs, and gutters occurred dominantly along NS- or NNE-trending streets, and so reflect shortening of this or similar orientation. Although most of the damage here was limited to concrete pavement, with adjacent asphalt typically devoid of cracks, broad asphalt surfaces in areas of highly concentrated deformation showed complex cracking that trended northwest (fig. 7).

The broad-scale swath of damage trends about N50W and extends from the Santa Teresa Hills at the south to Stanford University at the north. This swath contains four discrete zones of concentrated damage that trend from N30W to N65W (fig. 1; plate 1). Three of these zones lie near the southwestern valley margin, and one is situated farther north well away from the 
valley margin. The three zones of damage near the mountain front are here called the Los Gatos, Blossom Hill, and Los Altos-Cupertino zones; the zone north of the valley margin, which consists mainly of water-line breaks, is designated the Santa Clara zone (fig. 1). These zones are described separately below.

\section{LOSGATOSZONE}

The Los Gatos zone is a concentration of damage in and near downtown Los Gatos. It is about $2.5 \mathrm{~km}$ long in a northwest direction and has a width of about $1 \mathrm{~km}$ that includes the area between West Main Street and State Route 9. This zone is located mainly on alluvium that occupies a topographic reentrant carved by Los Gatos Creek into the bedrock uplands. Damage in this zone is the most severe and highly concentrated of the entire study area. This zone also contains the principal measured coseismic displacements in the study area (Ellen and others, in press; Peterson and others, in press).

The northwest-southeast length of the zone of damage is limited by the extent of concrete pavement; the few roads that cross likely extensions of this zone lack concrete components. Damage in this zone occurred mainly where long strips of concrete that trend NNE were thrust or buckled, suggesting a large component of shortening in this direction (plate 2). Similarly, the storm-drain grate shown in figure 5 displayed deformation consistent with northeastsouthwest shortening. Most of the damage recorded in this zone during our study consisted of contraction in concrete, but damage of other kinds, including damage to buildings, was abundant.

The belt of most severe damage within this zone trends about N35W. It extends northwest from breaks in the concrete median and asphalt surface of State Highway 17 through the lining of Los Gatos Creek, where we measured shortening of about $80 \mathrm{~mm}$ (Peterson and others, in press), toward cracks in an asphalt parking lot in downtown Los Gatos (plate 2). On trend between the creek lining and the parking lot were several contractional breaks in concrete, including at least one with measurable shortening (fig. 3). The parking lot, located just east of Santa Cruz Avenue between Royce Street and Grays Lane, showed complex cracks in the asphalt pavement, as well as crushed brick and cracked concrete in walkways and curbs. It was also a site of measured post-earthquake deformation. Northwest from the parking lot, this belt includes damaged buildings, numerous breaks in concrete pavement, and additional sites of post-earthquake deformation.

All sites of documented post-earthquake shortening in the study area occurred along the trend of concentrated damage within this zone. One site was in the sidewalk along the west side of Massol Avenue, south of the intersection with Almendra Avenue. Sidewalk slabs that buckled during the earthquake had been partly removed and repaired with an asphalt patch, which, by December 5,1989 , had shortened by about $24 \mathrm{~mm}$ along a thrust fracture (fig. 10). At a 


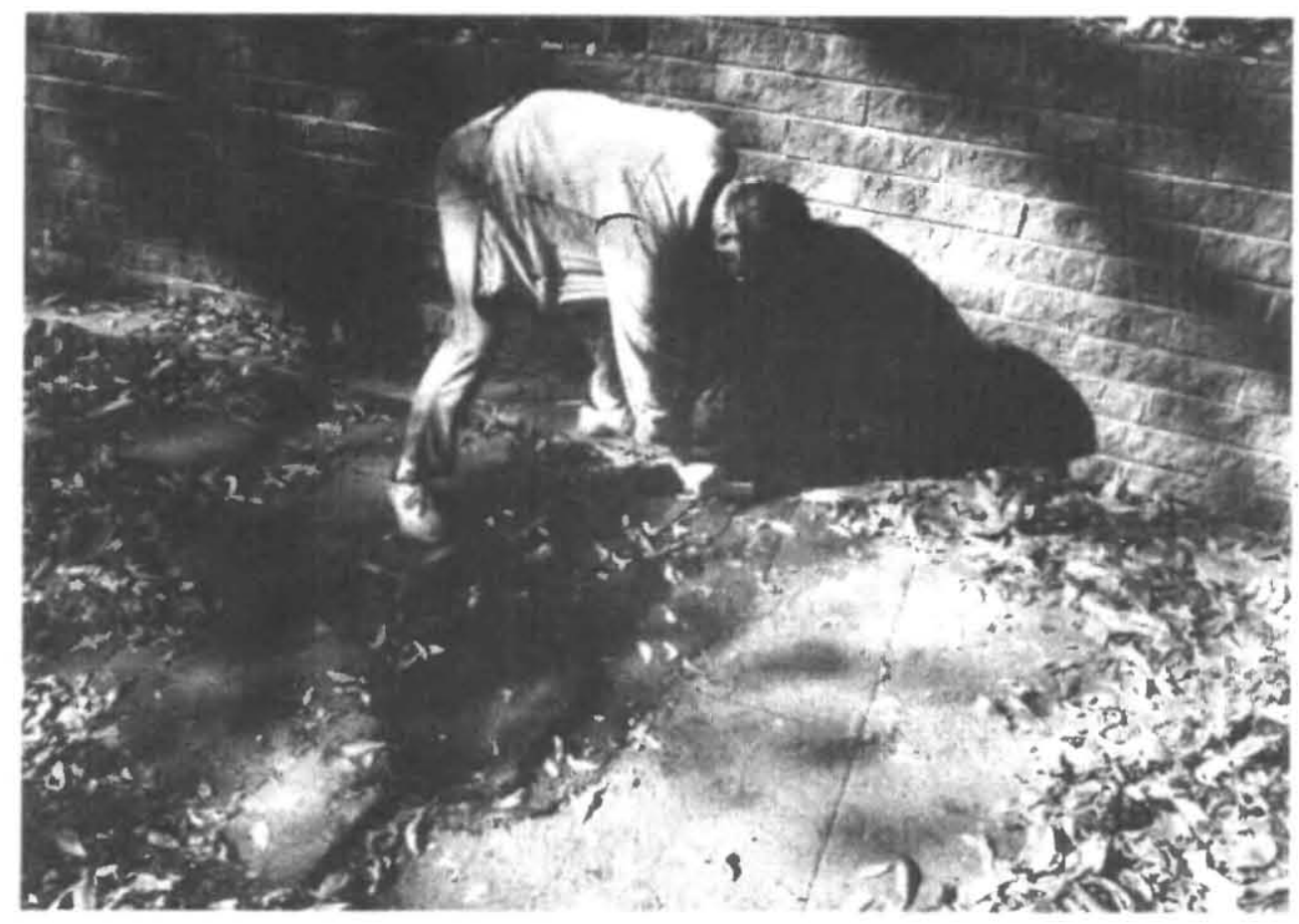

Figure 10. Post-earthquake thrust in asphalt patch of sidewalk in Los Gatos, on, Massol Avenue near Almendra Avenue, looking west. The asphalt patch, which replaced concrete sidewalk damaged by the earthquake, recorded about $2.4 \mathrm{~cm}$ of post-earthquake shortening by, December 5, 1989, the date of this photograph. Scale in hand is about $18 \mathrm{~cm}$ long. Adjacent wall (background) revealed no damage. Photograph taken December 5, 1989, by S.D. Ellen. 


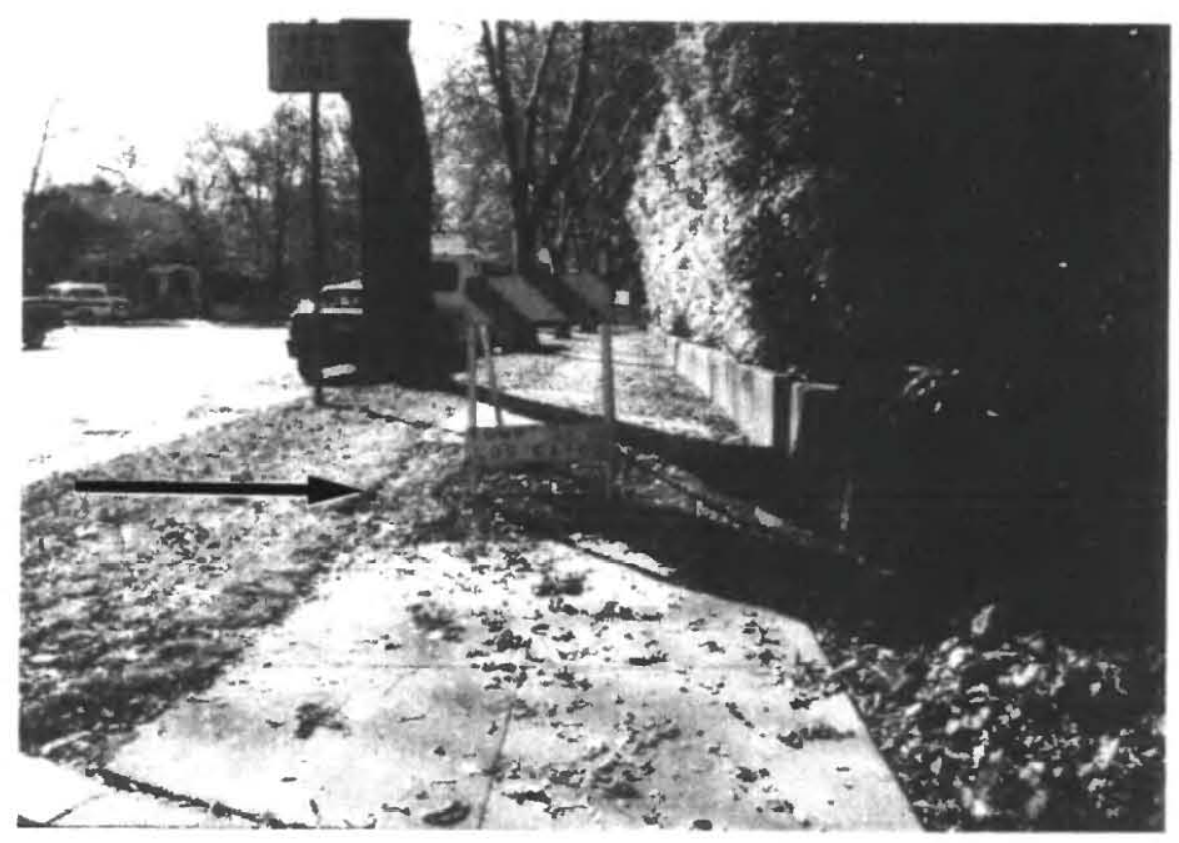

Figure 11A. Site of post-earthquake sidewalk deformation in Los Gatos, on Massol Avenue between Almendra Avenue and State Route 9. View to southwest shows asphalt patch, at site of post-earthquake thrust or tent in concrete sidewalk (denoted by arrow) that occupies abrupt step in otherwise straight stretch of sidewalk. Photograph taken December 5, 1989, by S.D. Ellen.

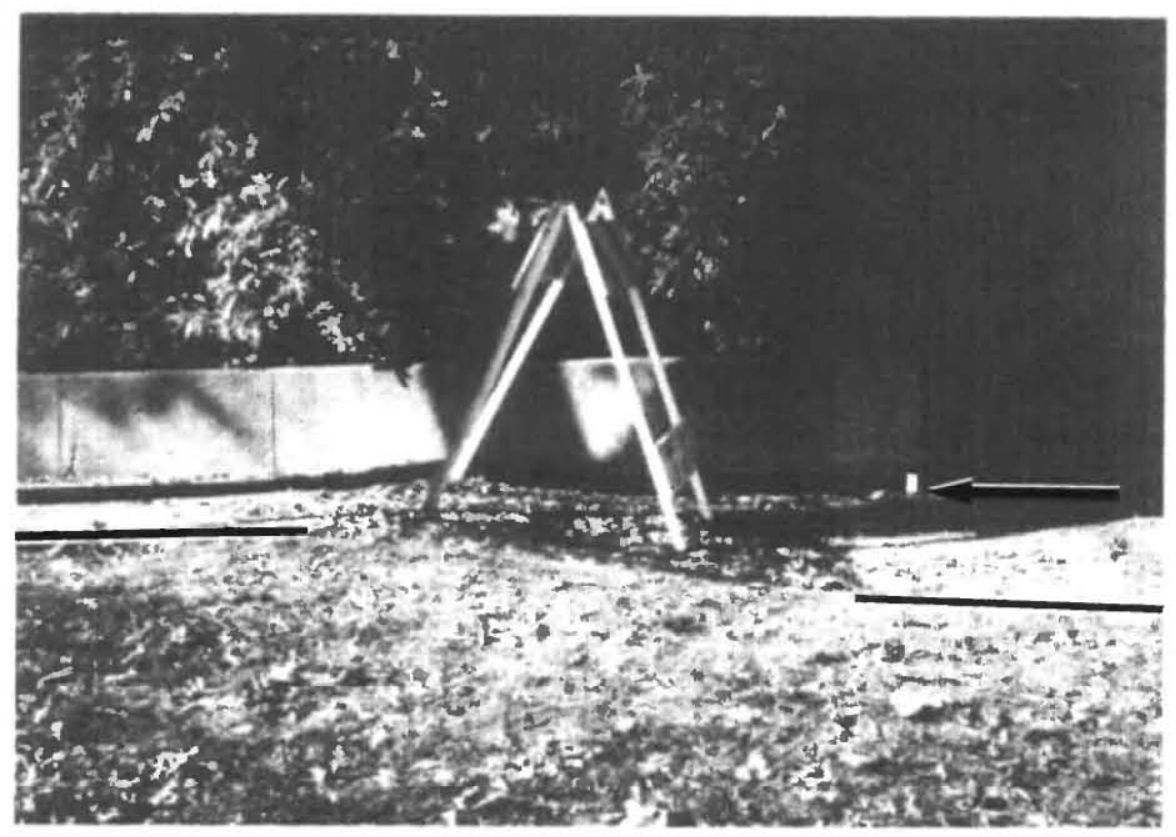

Figure 11B. Site of post-earthquake sidewalk deformation in Los Gatos, on Massol Avenue between Almendra Avenue and State Route 9. View to west reveals the relief of this step (highlighted edge of sidewalk), as well as suspended end of concrete wall (denoted by arrow) in background to right of traffic barricade. Photograph taken December 5, 1989, by J.C. Tinsley, U.S. Geological Survey. 
second site, in the parking lot mentioned above, three measurements were made by steel tape across a 27-m-wide zone that included the cracking in asphalt. The measurements, taken over the period from December 7, 1989, to July 13,1990, showed progressive shortening that totaled slightly more than $10 \mathrm{~mm}$. Although the measurements were crude, we consider the shortening so detected to reflect real ground deformation because 1) the measured shortening is far greater than the potential thermal contraction of the measuring tape, and 2) measurements of similar length at another site during the same period remained constant within $\pm 1.0 \mathrm{~mm}$. At two other locations along this trend of concentrated damage, concrete pavement deformed noticeably during the period between a day and a month after the earthquake, according to a U.S. Postal Service employee who walked the sidewalk daily to deliver mail (A. Morrisette, oral commun., 1989; fig. 11).

The Los Gatos zone includes the only known report of premonitory ground deformation in the study area. The sidewalk in front of a business on East Main Street near Maple Lane developed a fresh spall that was patched with asphalt during the two months before the earthquake. The concrete sidewalk and the old building at this site were then damaged during the earthquake. Old concrete patches in the sidewalk here, apparently to accommodate buckled sidewalk slabs, attest to a history of pre-earthquake deformation.

The Berrocal fault passes through the Los Gatos area as several subparallel strands that in detail show considerable complexity, including reverse faults that reveal northeastsouthwest shortening and related fault-parallel folds (Bailey and Everhart, 1964; McLaughlin, 1974; Sorg and McLaughlin, 1975; McLaughlin and others, 1991). The fault strands typically strike about N50W. They show both normal and reverse motion that locally offsets the folded gravels and finer grained materials of the Pliocene and Pleistocene Santa Clara Formation. One strand is a southwest-dipping thrust fault that parallels the mountain front near Main Street in downtown Los Gatos; the site of premonitory strain lies along this trace of the Berrocal fault. Concentrated damage within the Los Gatos zone, including all documented sites of postearthquake deformation, lies northeast of the mountain-front fault, on and between inferred and explicit traces of the Berrocal fault mapped by Bailey and Everhart (1964) and McLaughlin and others (1991).

In the foothills east of Los Gatos, coseismic offset along a strand of the Berrocal fault mapped by Bailey and Everhart (1964) and McLaughlin and others (1991) provided a link between fault-juxtaposed bedrock lithologies and damage to adjacent concrete pavement. A roadcut along Top of the Hill Road near Kennedy Road exposes this fault contact between sedimentary rocks and serpentinite. Fresh offset of a bench in the roadcut, as well as fresh breaks in bedrock of the shear zone (fig. 12A), indicated coseismic movement on this fault. Several meters along strike to the east, northeast-trending concrete curbs on both sides of Top 


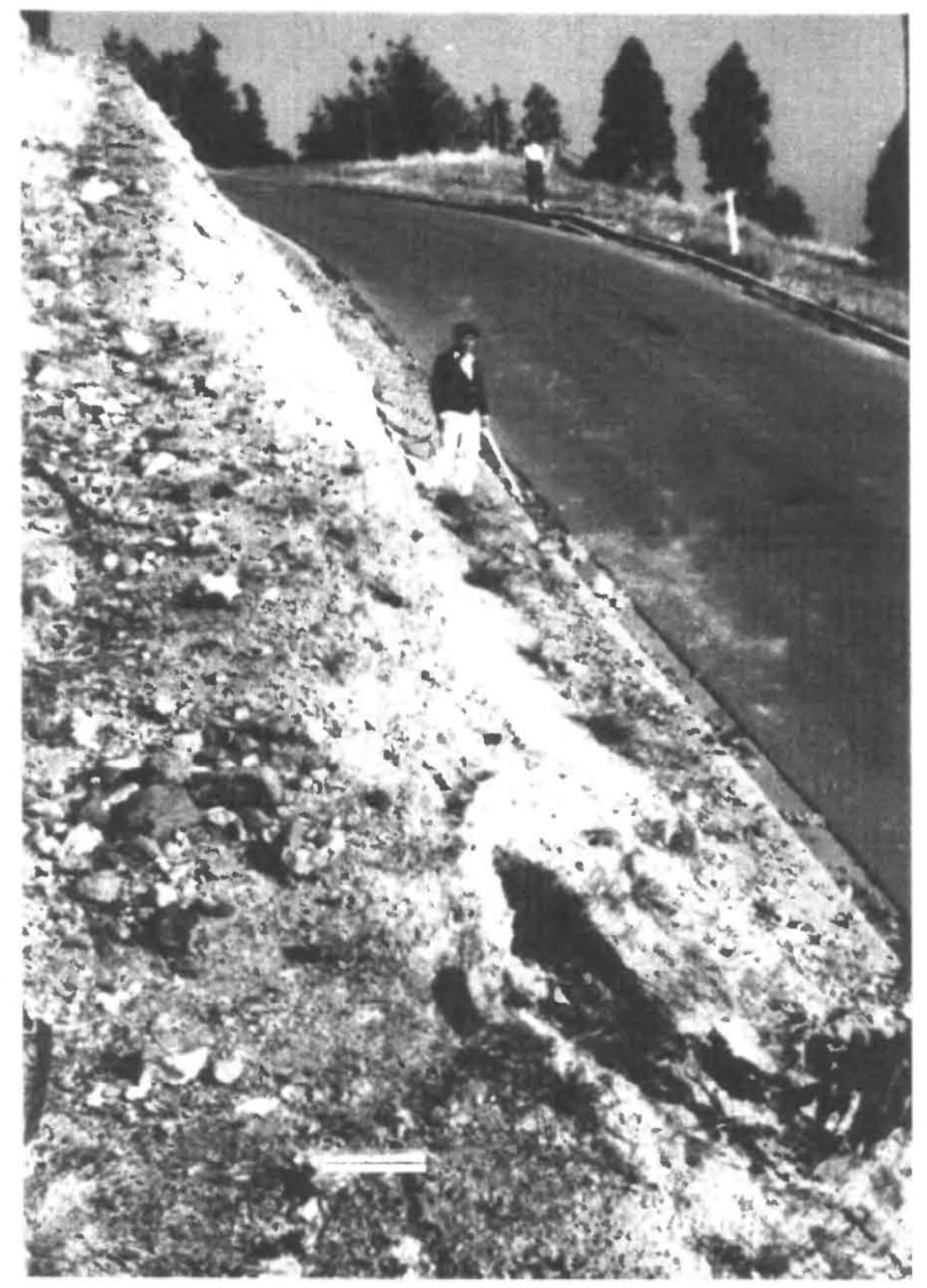

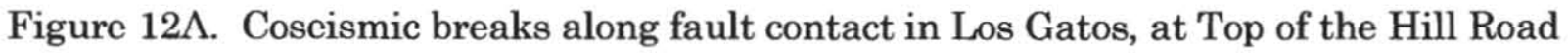
near Kennedy Road. View to east along alignment of breaks, from crack in bench of cut slope (foreground, at 18-cm-long highlighted ruler) to breaks in curbs near people in midground and background. Asphalt between broken curbs shows only minor cracks. Photograph taken November 4, 1989, by S.D. Ellen. 


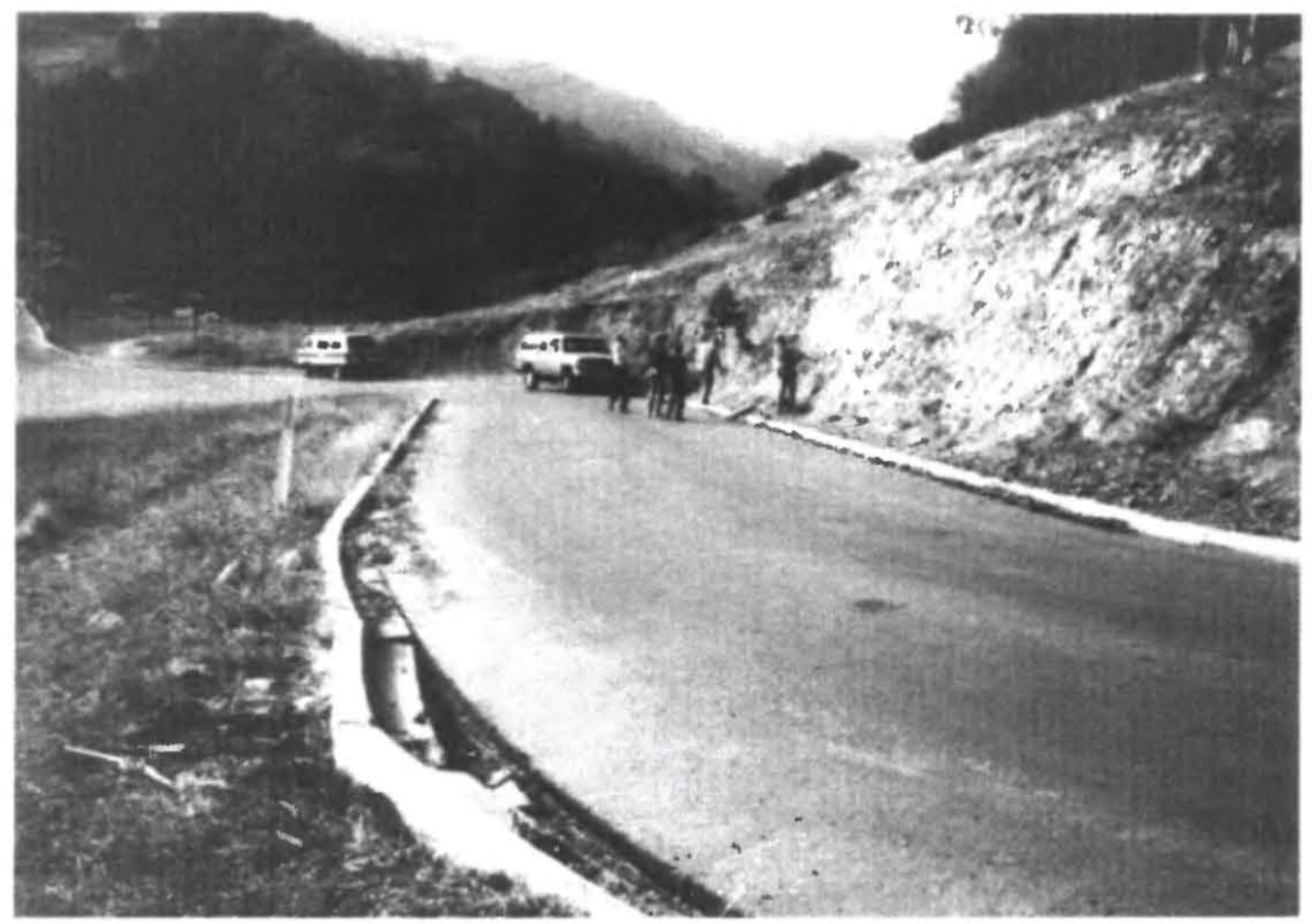

Figure 12B. Coseismic breaks along fault contact in Los Gatos, at Top of the Hill Road near Kennedy Road. View to west, opposite to view in (A), showing buckled curb shown in background of (A). Measurement of deformation indicates shortening of about $4-6 \mathrm{~cm}$ along the trend of the curb. The fault contact exposed in roadcut near people in the background separates sedimentary rocks (behind parked vehicles to left) from serpentinite (light colored rock at right). Fractures in rocks along contact showed fresh openings resulting from coseismic movement. Photograph taken December 5, 1989, by J.C. Tinsley, U. S. Geological Survey. 
of the Hill Road were deformed (figs. 12 A, B). Buckling of the easternmost curb indicated 40$60 \mathrm{~mm}$ of shortening along the trend of the curb. The asphalt road surface between the curbs showed minimal deformation.

\section{BLOSSOM HILL ZONE}

The Blossom Hill zone is an alignment of three major concentrations of damage within a larger band of less-concentrated damage (plate 1). The core of the zone, represented by the three concentrations, has a width of $400-800 \mathrm{~m}$ and extends from near the dam of Vasona Reservoir southeast for about $5 \mathrm{~km}$ along the foot of Blossom Hill. The full zone extends for about $13 \mathrm{~km}$ parallel to Blossom Hill, which is a fault-parallel syncline uplifted between strands of the Shannon fault (McLaughlin and others, 1991). Damage in this zone diminished progressively toward the southeast, possibly because of the diminishing occurrence of concrete. Toward the northwest, in an area of abundant concrete, scattered damage continued for only a few kilometers beyond Vasona Dam, but $5 \mathrm{~km}$ further along the same trend lay another concentration of damage, here called the Los Altos-Cupertino zone of damage.

The westernmost concentration of damage in the Blossom Hill zone extended to the southeast from near Vasona Dam, through Village Square shopping center, and through a residential area along Longridge Road (plate 2). The Village Square shopping center, located on Los Gatos Boulevard south of Gateway Drive, was the site of the most severe damage recognized within the Blossom Hill zone. Damage here was expressed as complex cracks in asphalt parking areas and streets (fig. 7), and as broken sidewalks and thrust curbs that suggested northeastsouthwest shortening (fig. 8).

The second concentration of damage in this zone occurred north of the western end of Blossom Hill, between Camino del Cerro and Pinehurst Avenue. In this area, breaks in concrete curbs, gutters, and sidewalks lay in gently sloping land Immediately northeast of Blossom Hill. The breaks formed two or three linear belts, about parallel to the foot of Blossom Hill, that cross NS-trending streets. The third concentration of damage was further east in similar gently sloping ground at the foot of Blossom Hill near Westhill Drive.

Damage at the Village Square shopping center coincided remarkably with a short isolated segment of faulted Quaternary alluvium mapped by Bailey and Everhart (1964). This fault segment lies along a branch of the Shannon fault that is largely concealed by alluvium (Bailey and Everhart, 1964; McLaughlin and others, 1991). Much of the damage near the foot of Blossom Hill, including the multiple linear belts of damage, is located on or near a series of young thrust faults mapped by photo-interpretation in 1981 by D.G. Herd (written commun., 1991). 


\section{LOS ALTOS-CUPERTINOZONE}

The Los Altos-Cupertino zone extends from the intersection of Page Mill Road and Highway 280 in Palo Alto southeastward to the city of Saratoga. This zone could be considered the northwestern extension of the Blossom Hill zone, but it is distinguished here for descriptive purposes. The zone contains two main clusters of damage that are somewhat isolated, probably by the paucity of concrete strain markers in the Rancho San Antonio County Park and the Gate of Heaven Cemetery. The northern cluster, which is located along Hwy. 280 near the town of Los Altos Hills, showed a broad distribution of damage near traces of the Monte Vista fault (plates 1, 2). In this area, numerous coseismic fractures in asphalt were observed (Sorg and Groffie, in press), along with abundant water-line ruptures. Damage to concrete was abundant near the intersection of Eastbrook Avenue and Mora Drive. Coseismic damage in part of this area, including damage to buildings, is discussed by Pampeyan and Loney (1995) and Sorg and Groffie (in press).

The other main focus of damage within the zone was in the vicinity of Cupertino, where a narrow band about $5 \mathrm{~km}$ long displayed a cluster of damage near the intersection of Regnart Creek and Bubb Road (plate 2, inset). Here a dense concentration of concrete breaks indicative of north-south compression was punctuated by a crack in asphalt more than $30 \mathrm{~m}$ long that trended N4OW (plates 1, 2). This deformation correlates with vegetation lineaments near the Regnart scarp, a 6-m-high northeast-facing escarpment (Hitchcock and others, 1994).

Like the Blossom Hill zone, the Los Altos-Cupertino zone follows traces of thrust faults mapped previously by D.G. Herd (written commun., 1991). Near Los Altos Hills, the damage coincides closely with traces of the Monte Vista fault as mapped by Herd (shown in Brabb and Hanna, 1981, and in Brabb and Olsen, 1986) and as reported by local geologic consultants (Leslie Ransbottom and Walter Dibble, written commun., 1990). In addition, local concentrations of coseismic damage coincide with several short segments of thrust faults in Quaternary alluvium that are shown in Herd's unpublished mapping.

The Stanford Linear Accelerator provided a particularly sensitive indicator of deformation near the northwest end of this zone. Laser measurement along the 3.2-km-long accelerator housing recorded two sites of coseismic fill settlement, each several millimeters in magnitude, and one site of abrupt permanent coseismic displacement totaling more than $10 \mathrm{~mm}$ of vertical offset (Fischer, 1989; Riordan, 1989).

\section{SANTA CLARAZONE}

The Santa Clara zone is a diffuse zone of damage situated in the city of Santa Clara, $8 \mathrm{~km}$ northeast from the Santa Cruz Mountains and the three other damage zones. It consists of water-line ruptures interspersed with less abundant concrete breaks. The zone is located on 
Quaternary alluvium $8 \mathrm{~km}$ south of the margin of San Francisco Bay, and trends roughly parallel to the zones of damage that lie along the foot of the Santa Cruz Mountains. The origin of the damage in this zone is especially elusive. Damage may have resulted from coseismic subsidence of the thick alluvium, but we consider this unlikely because the zone lies beyond the area of major subsidence related to ground-water withdrawal (Poland and Ireland, 1988). Unlike the other zones, the Santa Clara zone does not lie along mapped faults or breaks in slope. It does, however, lie in the general vicinity of the San Jose fault, which is a concealed fault inferred from aeromagnetic anomalies in the bedrock floor of the alluvium-filled basin (Brabb and Hanna, 1981; Carter and Jachens, 1993). Furthermore, a gradient in the gravity field coincides roughly with the damage zone (V.E. Langenheim, oral commun., 1996), and the map of thickness of alluvium in Santa Clara Valley (Bishop and Williams, 1974) shows a sharp break in basement topography directly beneath the concentration of damage. This abrupt break in buried bedrock topography may have arisen from fault offset.

\section{ANALYSIS}

Damage in the zones near the valley margin is consistent with that expected from movement of known fault systems, and in many cases with that expected from movement along previously identified fault traces (c.f. fig. 12). These zones show strong linearity parallel to the trend of known faults, both regionally and to lesser extent locally within each zone. Damage at many sites in these zones occurred on or near faults mapped by Bailey and Everhart (1964), McLaughlin (1974), Sorg and McLaughlin (1975), D.G. Herd (written commun., 1991), and McLaughlin and others (1991). Activity of some of these faults is suggested by geomorphic evidence, such as sag ponds, fault troughs, and stream diversions (Rogers and Williams, 1974; Hitchcock and others, 1994). Furthermore, the large relief and steep east-facing slopes of the southern Santa Cruz Mountains are thought to arise from active slip along mountain-front thrust faults (Bürgmann and others, 1994). Slip on such thrust faults would tend to move the southwest blocks upward to the northeast along the dipping fault planes, resulting in an overall northeast-southwest contraction of the ground surface. Recent tectonic activity is also indicated by a cluster of small earthquake epicenters near Vasona Dam between 1969 and 1974 (Sherburne and others, 1974; Brabb and Hanna, 1981) and by other seismicity that shows first-motion solutions consistent with mountain-front thrusting (Kovach and Beroza, 1993). The zones of concentrated damage near the valley margin thus suggest a tectonic origin because of 1) their linearity and broad-scale continuity, 2) their spatial association with mapped faults of likely activity, and 3) the NE-SW sense of shortening inferred from sites of damage a sense consistent with first motions of recent seismicity. 
The detailed orientations of contractional damage in concrete serve to further support the hypothesis that faults in the area underwent coseismic slip during the Loma Prieta earthquake. Whereas asphalt revealed no systematic sense of deformation, concrete appeared to serve as a sensitive strain gauge that provided significant information. As mentioned previously, the presence of expansion joints and pre-existing cracks in concrete permitted any extension or shear across the length of concrete strips to be accommodated without coseismic breaks, and so the concrete was forced to break only where shortening accumulated along the length of the concrete strips, typically over extents of tens of meters. Thus, the orientation of broken concrete strips would appear to reveal the orientation of shortening. A preponderance of breaks in sidewalks, curbs, and gutters along streets in only one orientation, for example, should indicate shortening approximately parallel to those streets, whereas breaks along both orientations of an orthogonal street pattern would indicate shortening in a direction oblique to both sets of streets. Breaks at street corners, where strips of both orientations converge, could reflect compression of any orientation relative to the street grid, which explains the abundance of these breaks. The orientations of shortening inferred in this manner from areas of welldefined orientations of concrete strips having mapped contractional breaks are shown by solid red circles on plates 1 and 2 . These orientations do not radiate from the earthquake epicenter, as might be expected if the damage were caused by shaking of the main shock, and the orientation at one locale seems unrelated to even the main rupture surface of the earthquake as modeled by Lisowski and others (1990). Rather, the damage to concrete has different orientations in different areas, and so appears to be related to local sources, such as nearby faults or folds. This information on orientation, combined with the distribution of damage in elongate zones, suggests that the damage documented in this report primarily reflects deformation related to local sources, such as sympathetic movement on pre-existing faults, rather than shaking from the main earthquake source.

Although much of the damage seems related to small, sympathetic movements on preexisting faults, other explanations are possible: 1) Permanent coseismic downwarping and associated contraction of the ground surface near Los Gatos, described by Ellen and others (in press), may account for some of the damage in the Los Gatos zone and for the relatively great breadth of this zone. 2) Abrupt changes in thickness or in seismic wave-propagation characteristics of alluvium, such as those occurring at the valley margin along parts of the Los Gatos, Blossom Hill, and Los Altos-Cupertino zones, can create the potential for local seismic amplification (Borcherdt, 1975), which could have contributed to damage in these areas. 3) The concentrations of damage near Los Gatos and Los Altos may have arisen from intensified ground shaking caused by reflection of seismic waves from the interface between the crust and mantle of the Earth. To test this hypothesis, Catchings and Kohler (1996) conducted 
controlled-source seismic experiments in the region. Their results indicate that seismic reflections from the Moho intensify ground shaking at discrete epicentral distances, which, from the Loma Prieta source, correspond to the Los Gatos, Los Altos, and Oakland areas. Their experiments, however, indicate that ground shaking intensified by this mechanism should occur in bands concentric to the epicenter. This orientation is roughly normal to the zones of damage shown in plate 1, suggesting that this mechanism was not a major contributor to the elongate zones of damage. 4) Three-dimensional modeling of seismic waves in the Santa Clara Valley, based on a Loma Prieta aftershock, revealed that duration of shaking, and thus hazard to longperiod structures such as pipelines and pavement, is a strong function of position in the basin (Frankel and Vidale, 1992). Sites near the edge of the basin, however, are predicted to experience a shorter duration of shaking than sites in the middle of the basin. Since the bulk of the observed damage is concentrated at the edge of the basin where durations would be expected to be short, it seems unlikely that this mechanism is responsible for most of the damage reported here.

\section{DISCUSSION}

The presence of contractional features along subsidiary faults parallel to the San Andreas fault zone is consistent with interpretations of regional tectonic strain partitioning along the transpressional plate margin of central California. The expression "strain partitioning" describes the occurrence of related subparallel faults and associated folds that together accommodate the strain generated at a plate boundary. The present boundary between the Pacific and North American plates is a complicated zone that exhibits both contractional and transverse deformation (McLaughlin, 1974; Aydin and Page, 1984; Zoback and others, 1987) in response to oblique convergence across the plate boundary (Harbert and Cox, 1989). As a result of the apparently negligible shear strength of the San Andreas fault system, the oblique strain in the lower crust or lithospheric mantle is partitioned upsection into nearly pure tangential and normal components of strain in the upper seismogenic crust (Zoback and others, 1987). It appears that the oblique slip at depth during the Loma Prieta earthquake, which consisted of $1.9 \pm 0.2 \mathrm{~m}$ of right-lateral slip and $1.3 \pm 0.4 \mathrm{~m}$ of reverse slip on the same fault plane (U.S. Geological Survey Staff, 1990), produced distributed coseismic strain at the ground surface. The area surrounding the trace of the San Andreas fault near the crest of the Santa Cruz Mountains demonstrated primarily lateral and extensional offsets in response to the Loma Prieta earthquake (Johnson and Fleming, 1993). In contrast, the region along the northeastern front of the Santa Cruz Mountains, which is dominated by reverse slip on planes subparallel to the San Andreas fault (Kovach and Beroza, 1993; Bürgmann and others, 1994), exhibited the 
damage documented here that is consistent with this sense of deformation. These two areas thus appear to represent the main types of surface manifestation of coseismic strain partitioning in the upper crust.

Although the San Andreas fault zone has been the topic of most seismic hazard evaluations, studies of deformation in western California (Lettis and Hanson, 1991; Montgomery and Jones, 1992) suggest that subsidiary faults in the region, such as those reflected in the damage described here, may potentially be more active than previously recognized. Our results suggest that reverse displacements have occurred sympathetically along the foot of the Santa Cruz Mountains in conjunction with a large-magnitude event along the San Andreas fault.

The style of damage described here is not unique to the Loma Prieta earthquake. In describing the Los Gatos area after the 1906 earthquake, Lawson and others (1908, p. 274) observed "... about a dozen upheavals of sidewalks, mostly on north and south streets." This account is remarkably similar to the 1989 damage north of Blossom Hill and in downtown Los Gatos. The general lack of concrete strain indicators in 1906 probably hindered the widespread development of recognizable deformation features. Similarly, southwest of Palo Alto near the intersection of the Monte Vista fault with Page Mill Road, damage occurred during both the 1906 (McLaughlin, 1974) and 1989 earthquakes, though the Loma Prieta damage was located to the north of the mapped fault trace, at the intersection of Page Mill Road and Hwy. 280 (plate 1).

Similar damage was noted following the San Fernando earthquake of February 9, 1971 (U.S. Geological Survey Staff, 1971; Bolt, 1975; Weber, 1975). Surface effects resulting from that earthquake suggested that faults other than those responsible for generating the earthquake were active during the earthquake, if only by intensified shaking along them. Also, faulting in bedrock below alluvium may have produced dissipated damage in alluvium at the ground surface (Weber, 1975). Evidence for tectonic thrust faulting during the San Fernando earthquake included a linear zone of ground breakage parallel to the front of the San Gabriel Mountains in the alluvial valley floor. Such examples suggest that the damage described here may be typical of other earthquakes.

\section{CONCLUSION}

Distribution of breaks in pavement and utility pipes, compiled from field observations and a comprehensive list of over 30 sources of information, show northwest-trending, discontinuous concentrations of damage arranged in four zones that roughly parallel the front of the Santa Cruz Mountains. Much of this damage shows a clear association with mapped northwest-trending faults that lie northeast of the San Andreas fault, and the northeast- 
southwest shortening reflected in much of the damage is consistent with the reverse or thrust nature of these faults. This concordance of damage and mapped fault traces suggests sympathetic movement on these smaller faults in response to the main shock of October 17, 1989. The distribution of damage documented here may help to refine the location of potentially active faults concealed by alluvial fill of the Santa Clara Valley. This study thus serves to document the damage in this area owing to the Loma Prieta earthquake and to promote understanding of the damage distribution so that concentrations of damage during future earthquakes can be predicted. 


\section{REFERENCES CITED}

Aydin, A., and Page, B.M., 1984, Diverse Pliocene-Quaternary tectonics in a transform environment, San Francisco Bay region, California: Geological Society of America Bulletin, v. 95, p. 1303-1317.

Bailey, E.H., and Everhart, D.L., 1964, Geology and quicksilver deposits of the New Almaden District, Santa Clara County, California: U.S. Geological Survey Professional Paper 360, 206 p., scale 1:24,000.

Bishop, C.C., and Williams J.W., 1974, Thickness of alluvium, Santa Clara County, California, in Rogers, T.H. and Williams, J.W., Potential seismic hazards in Santa Clara County, California: California Division of Mines and Geology Special Report 107, 39 p., scale $1: 62,500$.

Bolt, B.A., 1975, Earthquake risk in relation to earthquake characteristics, in G.B. Oakeshott ed., San Fernando, California, earthquake of 9 February 1971: California Division of Mines and Geology, Bulletin 196, p. 313-322.

Borcherdt, R.D., ed., 1975, Studies for seismic zonation of the San Francisco Bay Region: U.S. Geological Survey Professional Paper 941-A, 102 p.

Brabb, E.E., and Hanna, W.F., 1981, Maps showing aeromagnetic anomalies, faults, earthquake epicenters, and igneous rocks in the southern San Francisco Bay region, California: U.S. Geological Survey Geophysical Investigations Map GP-932, 6 p., scale 1:125,000, 3 sheets.

Brabb, E.E., and Olsen, J.A., 1986, Map showing faults and earthquake epicenters in San Mateo County, California: U.S. Geological Survey Miscellaneous Investigations Series Map I1257-F, scale 1:62,500, 2 sheets.

Brabb, E.E., Graymer, R.W., Jones, D.L., in prep., Geology of the Palo Alto $30 \times 60$ minute quadrangle, California: A digital database: U.S. Geological Survey Open-File Report 98$X X X$.

Bürgmann, R., Arrowsmith, R., Dumitru, T., and McLaughlin, R., 1994, Rise and fall of the southern Santa Cruz Mountains, California, from fission tracks, geomorphology, and geodesy, Journal of Geophyscial Research, v. 99, no. B10, p. 20,181-20,202.

Carter, W.R., and Jachens, R.C., 1993, Aeromagnetic map of the San Jose 1:100,000 scale quadrangle, California: U.S. Geological Survey Open-File Report 93-277, scale $1: 100,000,1$ sheet.

Catchings, R.D., and Kohler, W.M., 1996, Reflected seismic waves and their effect on strong shaking during the 1989 Loma Prieta earthquake: Bulletin of the Seismological Society of America, v. 86, p. 1401-1416. 
Ellen, S.D., Schmidt, K.M., Haugerud, R.A., Peterson, D.M., and Hamilton, J.C., in press, Geodetically measured coseismic ground deformation near Los Gatos, California: U.S. Geological Survey Professional Paper.

Fischer, G.E., 1989, SLAC site geology, ground motion and some effects of the October 17, 1989 earthquake: SLAC-Report-358, 19 p. plus appendices.

Frankel, A., and Vidale, J., 1992, A three-dimensional simulation of seismic waves in the Santa Clara Valley, California, from a Loma Prieta aftershock: Bulletin of the Seismological Society of America, v. 82, no. 5, p. 2045-2074.

Harbert, W., and Cox, A., 1989, Late Neogene motion of the Pacific Plate: Journal of Geophysical Research, v. 94, no. B3, p. 3052-3064.

Hitchcock, C.S., Kelson, K.I., and Thompson, S.C., 1994, Geomorphic investigations of deformation along the northeastern margin of the Santa Cruz Mountains, U.S. Geological Survey Open-File Report 94-187, 50 p., 2 pls.

Johnson, A.M., and Fleming, R.W., 1993, Formation of left-lateral fractures within the summit ridge shear zone, 1989 Loma Prieta, California, earthquake, Journal of Geophysical Research, vol. 98, no. B12, p. 21,823-21,837.

Kovach, R.L., and Beroza, G.C., 1993, Seismic potential from reverse faulting on the San Francisco Peninsula, Bulletin of the Seismological Society of America, v. 83, p. 597602.

Lawson, A.C., (ed.), 1908, The California earthquake of April 18, 1906: Report of the California State Earthquake Investigation Commission: Washington, D.C., Carnegie Institution, Publication 87, v. 1, 2 parts, 451 p.

Lettis, W.R., and Hanson, K.L., 1991, Crustal strain partitioning: Implications for seismichazard assessment in western California: Geology, v. 19, p. 559-562.

Lisowski, M., Prescott, W.H., Savage, J.C., and Johnston, M.J., 1990, Geodetic estimate of coseismic slip during the 1989 Loma Prieta, California, earthquake: Geophysical Research Letters, v. 17, no. 9, p. 1437-1440.

McLaughlin, R.J., 1974, The Sargent-Berrocal fault zone and its relation to the San Andreas fault system in the southern San Francisco Bay region and Santa Clara Valley, California: U.S. Geological Survey Journal of Research, v. 2, p. 593-598.

McLaughlin, R.J., Clark, J.C., Brabb, E.E., and Helley, E.H., 1991, Geologic map and structure sections of the Los Gatos 7-1/2' quadrangle, Santa Clara and Santa Cruz Counties, California: U.S. Geological Survey Open-File Report 91-593, scale 1:24,000. Montgomery, D.R., and Jones, D.L., 1992, Contemporary deformation in the California Coast Ranges and the preservation of evidence for Holocene offset, in Borchardt, G., and others eds., Proceedings on the Second Conference on Earthquake Hazards in the Eastern San 
Francisco Bay Area: California Department of Conservation, Division of Mines and Geology Special Publication 113, p. 281-288.

Pampeyan, E.H., and Loney, R.A., 1995, Preliminary maps showing location of reported damage and intensity of shaking in part of northern Santa Clara and southern San Mateo counties, California, from October 17, 1989 M 7.1 Loma Prieta earthquake: U.S. Geological Survey Open File Report 95-95, 9 p.

Peterson, D.M., Ellen, S.D., Schmidt, K.M., in press, Displacements in the concrete lining along Los Gatos Creek: U.S. Geological Survey Professional Paper.

Poland, J.F., and Ireland, R.L., 1988, Land subsidence in the Santa Clara Valley, California, as of 1982: U.S. Geological Survey Professional Paper 497-F, 61 p.

Riordan, M., 1989, SLAC survives a pretty big one: SLAC Beam Line, v. 19, no. 4, p. 3-5.

Rogers, T.H., and Williams, J.W., 1974, Potential seismic hazards in Santa Clara County, California: California Division of Mines and Geology Special Report 107, 39 p.

Sherburne, R.W., Williams, J.W., and Rogers, T.H., 1974, Seismicity map, Santa Clara County, California, in Rogers, T.H. and Williams, J.W., Potential seismic hazards in Santa Clara County, California: California Division of Mines and Geology Special Report 107, 39 p., scale 1:62,500.

Sorg, D.H., and Groffie, F.J., in press, Concentrated ground deformation and structural damage in the Monta Vista fault zone in Los Altos Hills area, Santa Clara County, California: U.S. Geological Survey Professional Paper.

Sorg, D.H., and McLaughlin, R.J., 1975, Geologic map of the Sargent-Berrocal fault zone between Los Gatos and Los Altos Hills, Santa Clara County, California: U.S. Geological Survey Miscellaneous Field Studies Map MF-643, scale 1:24,000.

U.S. Geological Survey Staff, 1971, Surface Faulting, in The San Fernando, California, earthquake of February 9, 1971: U.S. Geological Survey Professional Paper 733, p. 5576.

U.S. Geological Survey Staff, 1990, The Loma Prieta, California, earthquake: An anticipated event: Science, v. 247, p. 286-293.

Weber, F.H., Jr., 1975, Surface effects and related geology of the San Fernando earthquake in the Sylmar area, in G.B. Oakeshott ed., San Fernando, California, earthquake of 9 February 1971: California Division of Mines and Geology, Bulletin 196, p. 71-96.

Wentworth, C.M., 1993, General distribution of geologic materials in the southern San Francisco Bay region, California: a digital base map: U.S. Geological Survey Open-File Report 93-693, 12 p. 
Wentworth, C.M., Blake, M.C., ,McLaughlin, R.J., Graymer, R.W., in prep., Preliminary geologic map of the San Jose $30 \times 60$ minute quadrangle, California: A digital map image: U.S. Geological Survey Open-File Report 97-XXX.

Zoback, M.D., Zoback, M.L., Mount, V.S., Suppe, J., Eaton, J.P., Healy, J.H., Oppenheimer, D., Reasenberg, P., Jones, L., Rayleigh, C.B., Wong, I.G., Scotti, O., and C. Wentworth, 1987, New evidence on the state of stress of the San Andreas fault system: Science, v. 238 , p. $1105-1111$. 